PETTER LUNDBORG, ANTON NILSSON AND DAN-OLOF ROOTH

2014:4

\title{
Adolescent Health and Adult Labor Market Outcomes
}

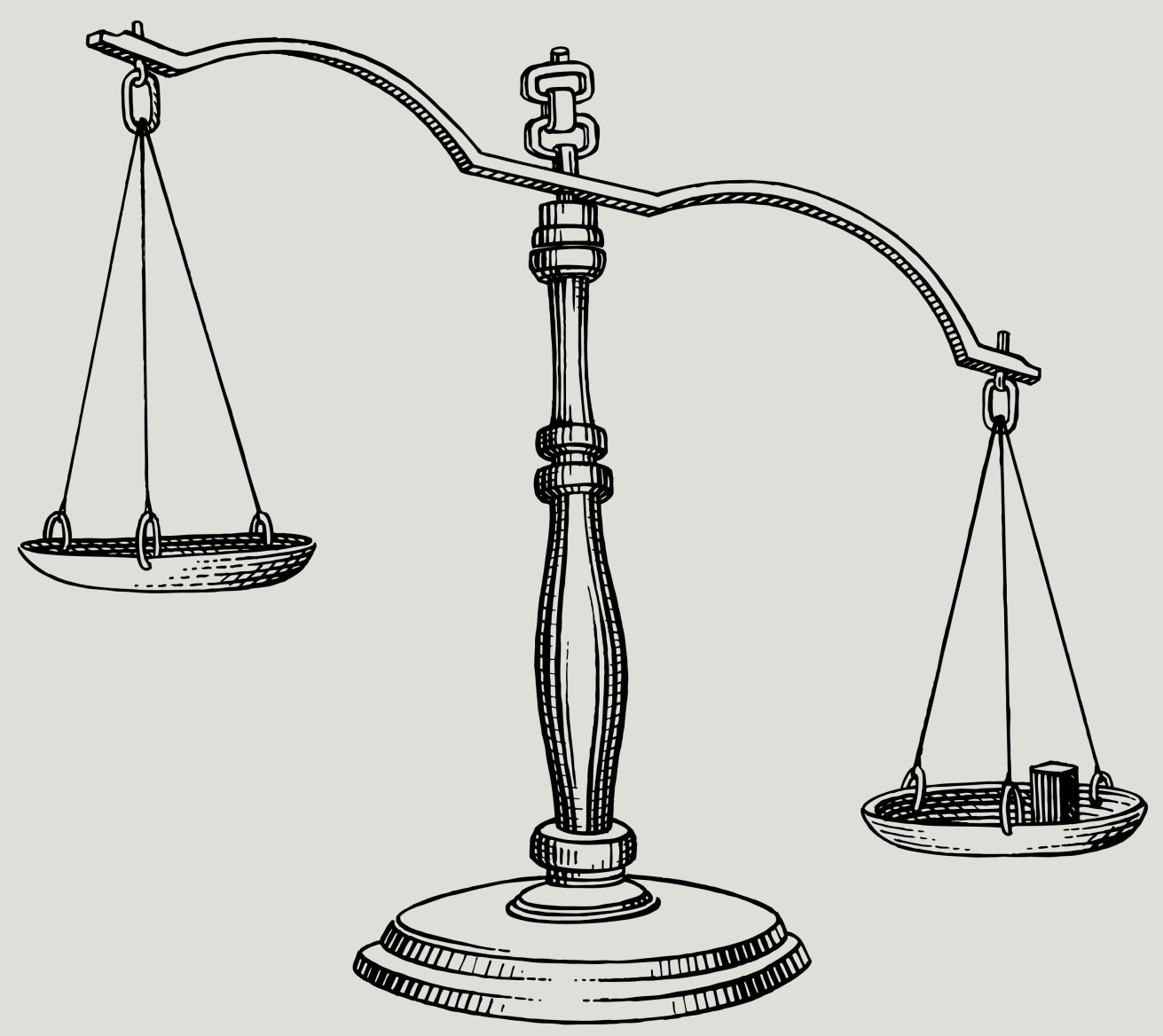

Linnæus University Centre 


\begin{abstract}
Whereas a large literature has shown the importance of early life health for adult socioeconomic outcomes, there is little evidence on the importance of adolescent health. We contribute to the literature by studying the impact of adolescent health status on adult labor market outcomes using a unique and large-scale dataset covering almost the entire population of Swedish males. We show that most types of major conditions have long-run effects on future outcomes, and that the strongest effects result from mental conditions. Including sibling fixed effects or twin pair fixed effects reduces the magnitudes of the estimates but they remain substantial.
\end{abstract}

Lundborg: Lund University (address: Dept of Economics, P.O. Box 7082, SE-220 07 Lund, Sweden; petter.lundborg@nek.lu.se), VU University Amsterdam, IZA, Tinbergen Institute, Centre for Economic Demography at Lund University, Health Economic Program at Lund University.

Nilsson: Lund University (address: Dept of Economics, P.O. Box 7082, SE-220 07 Lund, Sweden; petter.lundborg@nek.lu.se), Centre for Economic Demography at Lund University.

Rooth: Centre for Labour Market and Discrimination Studies, Linnaeus University (address: Kalmar Nyckel, SE-39182 Kalmar, Sweden; dan-olof.rooth@lnu.se), IZA, CReAM, Centre for Economic Demography at Lund University. 


\section{Introduction ${ }^{1}$}

An adult's success in the labor market importantly depends on his or her health status already before adulthood. This is suggested by a growing literature that links measures of early life health to various adult outcomes, such as education and earnings (Currie 2009; Almond and Currie 2011). Since individuals with poor health are disproportionally to be found in families of lower socioeconomic status, this implies that childhood and adolescent health may be an important factor in understanding how socioeconomic status is transmitted across generations. In order to design policies that prevent the disadvantaged from falling behind, and thus increase intergenerational mobility, more detailed evidence on the link between poor health and subsequent outcomes is however needed.

At this point, most of the research on the relationship between early health and adult labor market outcomes has focused on measures of very early health. In particular, a number of studies in the economics literature have shown the importance of birth weight for outcomes such as education, earnings, and cognition (e.g., Currie and Hyson 1999; Behrman and Rosenzweig 2004;

${ }^{1}$ The authors thank Janet Currie and seminar participants at Lund University, at the Health and Human Capital Workshop in Mannheim, at the RGS Doctoral Conference in Duisburg, at the RES Conference in Cambridge, at the ASHE Conference in Minneapolis, at the EEA Conference in Gothenburg and at the EALE Conference in Turin for useful comments and suggestions. We also thank Ingvar Ahlstrand and Björn Bäckstand at the National Service Administration for providing information on the enlistment data and procedure. Research grants from the Swedish Council for Working Life and Social Research and from the Centre for Economic Demography (CED) at Lund University are gratefully acknowledged. 
Black et al. 2007; Royer 2009; Bharadwaj et al. 2013; Figlio et al. 2013). At birth, however, many health problems that manifest themselves during childhood and adolescence have not yet emerged and they would thus not be reflected in lower birth weight. But only a few studies have considered the importance of health status during childhood and adolescence for adult outcomes.

Case et al. (2005) used the 1958 British birth cohort study to show that adults that had suffered from chronic conditions at age 7 or 16 had lower educational attainment, lower employment probabilities and lower earnings. Smith (2009) exploited data from the Panel Study of Income Dynamics (PSID) and used a sibling fixed effects design to analyze the relationship between retrospectively measured overall health up to age 16 and adult labor market outcomes. The results suggested a strong relationship between health at age 16 and outcomes such as earnings, wealth, and labor supply.

Also applying a sibling design, Currie et al. (2010) used data from public health insurance records for 50,000 children and adolescents aged 18 and younger born in Manitoba, Canada. Rather than using an overall indicator of health, a multitude of different health problems including mental conditions, asthma, injuries, and congenital/perinatal problems, was linked to educational outcomes and to the probability of receiving social assistance in young adulthood. ${ }^{2}$ While their study improved on the previous literature by analyzing the effects of specific diagnoses, it was more limited in terms of outcomes. As noted by the authors, "It would be very interesting to be able to measure adult earnings or employment status, but this information is currently unavailable." (Currie et al. 2010, p. 534).

${ }^{2}$ For mental problems, they focused on ADHD and conduct disorders, but noted that similar results were obtained when using a broad group of mental conditions. 
We contribute to the literature on the relationship between adolescent health and adult outcomes by exploiting a unique dataset covering almost the entire population of Swedish males born between 1950 and 1970. The dataset has information on a large set of health measures obtained from a medical examination at the age of 18, including most of those analyzed by Currie et al. (2010), but also many others. It also includes data on adult labor market outcomes such as earnings, taken from registers.

In addition to enabling us to link health problems to labor market outcomes, our data offers several key advantages. First, since military enlistment was mandatory during the study period, our data covers more or less the entire population of males. We therefore do not have to worry that our results reflect differences in healthcare-seeking behavior, which might affect studies relying on hospital or insurance records. In addition, our full population data gives our results an unusually high degree of representativeness.

Second, our health data are based on obligatory assessments of individuals' health conducted by a physician. As a result, we do not have to rely on self-reports, which have been shown to suffer from issues such as justification bias or differences in expectations. ${ }^{3}$ For simplicity and in order to increase precision, studies using self-reported health (e.g., Smith 2009)

\footnotetext{
${ }^{3}$ In the retirement literature, for example, it has long been recognized that individuals are
} likely to provide different evaluations of their health depending on their expectations or because they may justify their retirement decision by exaggerating their health problems (e.g., McGarry 2004; Lindeboom and Kerkhofs 2009). d'Uva et al. (2008) show that health reporting differs by education level and that measured health inequalities by education are often underestimated if these differences are not taken into account. 
have typically used self-reported indicators of overall health. Our data also includes an indicator of overall health, but has the advantage of not being self-reported but determined by a physician.

Third, our data allows us to compare outcomes and health between more than 275,000 sibling brothers. Like Smith (2009) and Currie et al. (2010) we are thus able to control for all unobserved factors at the family level. In addition, we are able to identify a relatively large sample of monozygotic twins in our data. This allows us to further difference out the influence of unobserved endowments, such as genes. With the exception of studies using birth weight and other measures of health already around birth, we believe our study is the first to estimate the effect of health on subsequent earnings using data on monozygotic twins. ${ }^{4}$

Fourth, our data includes cognitive and non-cognitive test scores. We are thus able to control for ability differences between siblings, while evaluating the impact of adolescent health. Without such controls, one risks confounding the effect of health with that of ability, since some previous studies, such as Case and Paxson (2008) and Lundborg et al. (2013), have shown that the returns to height, when treated as an indicator of childhood health, is substantially reduced when accounting for cognitive abilities.

Our results suggest a strong relationship between health at age 18 and adult earnings both with and without sibling fixed effects, although the estimates are in virtually all cases reduced with the introduction of these fixed effects. In line with Currie et al. (2010) we find relatively

\footnotetext{
${ }^{4}$ Estimating the relationship between health and academic achievement, Fletcher and
} Lehrer (2009) used genetic markers to show that sibling fixed effects remove some, but not all, of the endogeneity of health. Since we do not have data on genetic markers, we can try to further remove the endogeneity either by using twins or by adding control variables. 
small effects of asthma, injuries and congenital anomalies, but large effects of mental problems. In particular, having a mental condition at age 18 is found to give rise to an adult earnings penalty of about 20 percent when sibling fixed effects are included. Moreover, our analysis suggests strong negative effects or conditions of the nervous system and of endocrine, nutritional and metabolic conditions.

The paper is organized as follows. Section 2 describes our data in greater detail, and section 3 we introduce our empirical model. Section 4 presents the results, whereas Section 5 provides some concluding remarks.

\section{Data}

\section{A. Data description}

Our dataset is based on two databases that have been linked together. First, information on individuals' health status, cognitive ability and non-cognitive ability was obtained from military enlistment records from 1969-1997. These were provided by the Swedish National Service Administration (Pliktverket). Second, information on educational attainment, occupation, earnings and marital status was provided by Statistics Sweden (Statistiska centralbyrån). Almost all individuals can be linked to their parents, which enables us compare outcomes between brothers. Similar data were also used by Lundborg et al. (2014).

At the time period under study, the Swedish military enlistment test was mandatory for men, with exemptions only granted for institutionalized individuals, prisoners, and individuals living 
abroad. Individuals usually underwent the examinations at the age of 18 or $19 .{ }^{5}$ Refusal to enlist was punishable with a fine, and eventually imprisonment, implying that the attrition in our data is very low; only about 3 percent of each cohort of males did not enlist.

The military enlistment records include up to six medical conditions for every individual, coded according to the ICD8 classification (WHO, 1967). Any health problem, present or historic, that may interfere with the individual's ability to undergo military service is supposed to be recorded, whereas other and less important health problems are not supposed to be recorded. There is also a unidimensional health measure, which we refer to as "global health". This is based on the severeness of the individual's health conditions (both physical and mental) and is used by the National Service Administration to determine the individual's suitability with respect to type of military service.

All diagnoses were recorded by a physician and are based on a health declaration form that the individual had filled in at home and had to bring with him, combined with a general assessment of his health lasting for about 20 minutes. Individuals were expected to bring any doctor's certificate, health record, drug prescription or similar proving that he actually suffered from the conditions he had reported in his health declaration, making "cheating" more difficult. Individuals not providing such evidence, but claiming to suffer from a specific health condition, could be forced to visit a hospital or health care center to obtain a doctor's certificate, and then continue the examination at a later point.

${ }^{5}$ Up until 1972, a majority of individuals were called to undergo the military enlistment tests the year they turned 19, whereas in later years most individuals underwent the enlistment test the year they turned 18 . 
The global health measure included in our data is expressed with letters from A to $\mathrm{M}$ (except "I"), or "U", "Y", or "Z". The closer to the start of the alphabet the letter assigned to the individual is, the better his general health status is considered to be. "A" thus represents more or less perfect health, which is necessary for "high mobility positions" (such as light infantry or pilot) and has been assigned to about 60 percent of all individuals for which there is non-missing data. For combat positions, individuals must have been assigned at least a "D", and individuals with a "G" or lower are only allowed to function in "shielded positions". Individuals that have been assigned a "Y" or "Z" (in total $8 \%$ of the individuals) are not allowed to undergo education within the military. "U" (assigned to less than $1 \%$ of all individuals) indicates that global health status has not been decided, and we treat this as missing. The global health measure to be used in our analysis is created by transforming " $\mathrm{A}$ " into 0 , " $\mathrm{B}$ " into 1 etc.; "Y" into 12 and "Z" into 13 .

In our analyses of health conditions, we construct 13 broad categories which cover 94 percent of all conditions reported in our full sample. In creating these categories, we essentially followed the "chapters" provided by the ICD8 classification, with the only exception that we split the category of "conditions of the nervous system and sensory organs" into one category of conditions of the nervous system and one category of conditions of the sensory organs. ${ }^{6}$ This leaves us with the following categories of health conditions: tumors; endocrine, nutritional and metabolic conditions; mental conditions; conditions of the nervous system; conditions of the sensory organs; circulatory conditions; respiratory conditions; digestive conditions; genitourinary conditions; skin conditions; conditions of the musculoskeletal system and connective tissue; congenital anomalies; and, injuries.

\footnotetext{
${ }^{6}$ The ICD8 codes for these are 320-358 and 360-389, respectively.
} 
In addition to these broad categories of health problems, we analyze a number of specific and common types of diagnoses. These include diabetes (an endocrine condition), neurosis, personality disorder and alcoholism and drug dependence (mental conditions), epilepsy and migraine (conditions of the nervous system), asthma and hay fever (respiratory conditions), and vertebrogenic pain syndrome (a condition of the musculoskeletal system). ${ }^{7}$ Previous literature has documented correlations between these conditions and adverse labor market outcomes. ${ }^{8}$ In particular, it is of crucial interest to compare our results for asthma, congenital anomalies, injuries, and mental conditions with those of Currie et al. (2010), since their health measures were also determined prior to adulthood.

Cognitive ability is measured using a test similar to the Armed Forces Qualification Test (AFQT) in the US. It includes four subtests measuring logical, verbal, spatial, and technical abilities. Based on the test, individuals have been assigned a number between one and nine taken from a distribution which is close to normal. For the analysis, we use a standardized version of this number.

Non-cognitive ability is also measured on a scale between 1 and 9 , which approximates a normal distribution. The assignment of this number is done by a psychologist, based on a semistructured interview lasting for about 25 minutes. The objective of this interview is to determine the individual's ability to cope with the psychological requirements of the military, and in

\footnotetext{
${ }^{7}$ The ICD 8 codes for these are 250, 300, 301, 303-304, 345, 346, 493, 507, and 728 .
}

${ }^{8}$ See, for example, Ng et al. (2001), Ettner et al. (1997), Ettner et al. (2011), Famulari (1992), Ferrari (1998), Krahn et al. (1996), Malone et al. (1997), Fanning (1981), and Currie et al. (2010). 
particular this implies an assessment of personal characteristics such as willingness to assume responsibility, independence, outgoing character, persistence, emotional stability and power of initiative (Lindqvist and Vestman 2011). In addition, an important objective of the interview is to identify individuals who are considered particularly unsuited for military service, which includes individuals with antisocial personality disorders, individuals with difficulty accepting authority, individuals with difficulties adjusting to new environments and individuals with violent and aggressive behavior (Andersson and Carlstedt, 2003; Lindqvist and Vestman 2011). It is thus by definition true that this variable is endogenous at least to some mental conditions. For our empirical analysis, we proceed similarly as for cognitive ability and standardize the non-cognitive ability variable by birth year using all individuals with non-missing data on this variable. Lindqvist and Vestman (2011) have previously shown that both our cognitive and non-cognitive measures strongly predict adult earnings in the population of Swedish males.

We use register data on individuals' educational attainment, occupational choice, marital status and annual earnings from 2003. The latter refers to income from work and self-employed income. Educational attainment is expressed in terms of the highest degree attained. Our measure of years of schooling is assigned based on the standard number of years of schooling associated with this degree. We choose to standardize this variable in order to make it comparable with cognitive and non-cognitive ability.

Occupation is categorized into 115 different groups according to SSYK (Standard for Swedish Occupational Classification), a three digit occupational classification code similar to the international classification (ISCO). Moreover, marital status is categorized into seven different groups ("unmarried", and "married", "divorced", and "widower", as well as their same-sex equivalents). Our most extensive models will include fixed effects for all occupation and marital 
status categories, allowing us to determine whether the lower earnings observed among individuals with health problems may be due to sorting into certain occupations or types of marital status.

\section{B. Sample constructions}

The oldest cohort available was born in 1950. At the younger end, we choose to only include individuals born up until 1970. This is for two reasons. First, younger individuals may not have finished their education as of 2003 or may be temporarily employed in jobs that do not fully correspond to their productivity level. Second, beginning in 1989, diagnoses were reported by the National Service Administration using the ICD9 instead of the ICD8 classification. Since ICD8 and ICD9 codes are not fully comparable, it would thus make our results somewhat less straightforward to interpret had we included later born individuals.

In order to avoid selection issues, we exclude the small number of women volunteering for the military. Similarly, we only include native Swedes, that is, individuals born in Sweden to Swedish-born parents. This is to sort out non-Swedish citizens, who are not obliged to undergo military service in Sweden and, in addition, avoid issues of ethnic discrimination.

Our sources provide us with a population of 772,939 native Swedish males born between 1950 and 1970 with non-missing data on global health status. ${ }^{9}$ We use the 319,145 individuals for which at least one brother is also available. Moreover, most of our discussion will center on

${ }^{9}$ For most cohorts, about 3 percent of the male population lacks data on global health status, usually because they didn't enlist. 
individuals with positive earnings. There are 275,534 individuals with positive earnings and for which at least one brother with positive earnings is also available.

In an attempt to account for unobserved characteristics possibly to an ever higher degree than can be done with siblings, we have also obtained information on twins and their zygosity from the Swedish Twin Registry ${ }^{10}$ (“Svenska tvillingregistret”). Genetically, dizygotic (DZ) twins are as similar as siblings but they share more similar environments. If estimates based on DZ twins yield much smaller estimates than estimates based on siblings, we may conclude that relationships are largely driven by unobserved environmental variables. Monozygotic (MZ) not only share similar environments but also share the same DNA, which further allows us to fully control for genetic factors. Applying the same restrictions as above, our data includes 6,478 individuals from complete twin pairs and for which both twins are observed to have positive earnings. Of these, 2,232 are monozygotic, 3,024 are dizygotic and 1,222 are of unknown zygosity.

Some individuals have missing values on years of schooling, cognitive ability or noncognitive ability. We replace missing values with the individual's siblings' average on the variable, and we add binary variables indicating the presence of missing data as well as interactions between all the health variables and these indicators.

${ }^{10}$ Detailed information on the Swedish Twin Registry can be found in Lichtenstein et al. (2006). 
Descriptive statistics for our main estimation sample are shown in Table $1 .{ }^{11}$ Regarding health, it can be seen that about 50 percent of all individuals were diagnosed with some condition. Conditions of the sensory organs and conditions of musculoskeletal and connective tissue are the largest groups, with prevalences of 15.6 and 13.5 percent, respectively. The smallest groups are tumors and genito-urinary conditions, which only affect 0.2 and 1.3 percent of all individuals.

\section{$<$ Table 1 about here $>$}

For a comparison, Table 1 and 2 in the Web Appendix lists U.S. prevalences of the diagnoses and groups of diagnoses that we use. These are obtained from sources such as the National Health Interview Survey (NHIS) and the National Survey of Children's Health (NSCH). To the extent possible, we have listed prevalences for males around the age of 18. In general, the prevalences in our data are similar the ones reported by these sources, but ours tend to be somewhat lower. This can probably be attributed to the fact that only health problems that may interfere with an individual's ability to undergo military service has been recorded by the National Service Administration. For mental health problems, the literature provides a broad range of estimates since the criteria for diagnosing individuals with mental disorders can be applied more or less

${ }^{11}$ Table A1 shows descriptive statistics for the sample not restricted to individuals with positive earnings, whereas Table A2 shows descriptive statistics for the sample not restricted to individuals with at least one brother. The differences compared to Table 1 are small. 
strictly. Our prevalences fall at the lower end of those reported by other sources, suggesting that relatively minor mental problems are not included in our data. ${ }^{12}$

\section{Empirical method}

Investigating the penalties of different types of health problems, we run regressions of the following form:

1) $\quad Y_{i j}=a+b^{*} H_{i j}+c^{*} X_{i j}+f_{j}+e_{i j}$.

Here, $i$ is index for individual and $j$ for mother. $H$ is either a scalar representing global health, a vector of the different categories of health conditions, or a vector of the specific conditions that we analyze. ${ }^{13} X$ is a vector of individual characteristics including cognitive and non-cognitive ability, schooling, occupation, marital status, and dummies for year of birth. $f$ represents sibling (or twin) fixed effects which capture characteristics that are common to the brothers. The identification of $b$ relies on within-siblings variation in health variables. We focus on

${ }^{12}$ One might perhaps worry that vertebrogenic pain syndrome is a condition that some individuals would try to "fake" at enlistment, but the prevalence of this condition in our data (5.6 percent) is not high compared to prevalences of back pain reported elsewhere in the literature. Olsen et al. (1992) found that 7.3 percent of adolescents had suffered from lower back pain seeking medical attention and that as many as 30 percent of adolescents had experienced problems at some point in time.

${ }^{13}$ We also include a dummy for "all other" conditions. 
specifications where $Y$ is the logarithm of annual earnings, but we also explore specifications where the outcome is an employment indicator and where the outcome is (sickness-related) welfare benefits as a share of annual income. ${ }^{14,15}$

Previous studies (e.g., Currie et al. 2010; Salm and Schunk 2012) have argued that child or adolescent abilities are influenced by health problems. To the extent that this is the case, individuals' abilities should rather be viewed as mediators of the relationship between health problems and later labor market outcomes, and should not be controlled for when estimating the net causal effect of health. On the other hand, one could think of many ways in which health and abilities are correlated without abilities being the outcome of health status. For example, both cognitive and non-cognitive abilities are negatively related to risky behaviors such as criminality and daily smoking at age 18 (e.g., Heckman and Rubinstein 2001). These behaviors may, in turn, lead to health problems, for example respiratory conditions and injuries. Parental behaviors or other environmental factors may affect both health and abilities of children, creating a spurious correlation between the two, although this will be accounted for by our sibling fixed effects model whenever these factors affect different siblings similarly.

\footnotetext{
${ }^{14}$ We use benefits as a share of income because benefits are typically determined based on the individual's income.

15 Since some studies (e.g., Case et al. 2002) suggest that the effect of poor effect may differ depending on parental socioeconomic status, we have also run specifications where health was interacted with parental income or educational attainment. We did not find any evidence of such heterogeneous effects, however.
} 
Since it is not clear how health is related to abilities, schooling and other variables, we take an agnostic approach and run several different models with different sets of controls. Assuming that correlations between health and controls partially reflect causal effects of health, that all controls included have the effect of lowering the estimated earnings penalty, and that no other confounding mechanisms are at play, estimates from models without these controls can be seen as upper bounds whereas estimates including all of these can be seen as lower bounds of the effects of health status at the age of 18 on earnings later in life.

\section{Results}

\section{A. Global health}

We start our analysis by analyzing our aggregate measure of health, "global health". As can be seen in Model A in Table 2, global health status at the age of 18 is a strong predictor of adult earnings. According to the estimate, an increase in bad health by ten steps, which corresponds to the difference between "perfect" health and a health status just somewhat better than required for military service, implies a 25 percent decrease in earnings. ${ }^{16}$ Given conventional OLS estimates

16 The same result is obtained when not restricting the sample to individuals with at least one brother available. Throughout our results, we obtain similar OLS estimates when not restricting attention to individuals with at least brother, suggesting that our sibling sample is representative of a larger population. 
of the returns to schooling, this is an effect equivalent of about 3-5 years of education. As no controls have been included, however, this estimate should be considered as an upper bound. ${ }^{17}$

\section{$<$ Table 2 about here $>$}

To account for unobserved factors at the family level, Model B adds sibling fixed effects. This reduces the penalty, but only by about 30 percent, showing that such unobserved factors are not the main driver of the health-earnings relationship. Furthermore, adding a control for education as in Model $\mathrm{C}$ has little effect, largely because of a weak relationship between health and schooling. This finding is in line with Smith (2009) who found a large effect on overall health on earnings, but no significant effect on educational attainment. ${ }^{18}$

${ }^{17}$ One may ask whether it is reasonable to use a linear indicator of global health, i.e., whether the difference between, for example, " $A$ " and " $B$ " has the same effect on log earnings as the difference between " $\mathrm{M}$ " and "Y". Figure 1 shows the coefficients and confidence intervals from a regression where we instead used dummies for different levels of global health. "A" is the omitted category. Indeed, the figure suggests a rather linear relationship between global health and log earnings.

18 Moreover, in another paper using Swedish military enlistment data, Lundborg et al. (2011) found no evidence of a relationship between health at age 18 and final educational attainment within pairs of $\mathrm{MZ}$ twins. Given that $\mathrm{MZ}$ twins are representative of a larger population this may suggest that health has little or no causal effect on educational attainment. 
Cognitive and non-cognitive abilities affect earnings about as much as schooling does, but controlling for these instead of schooling (Model D) leads to a much larger reduction of the earnings penalty, which decreases by about a half to -8 percent. Finally, our extended model (Model E) controls for both schooling and abilities, as well as occupation and marital status. The resulting penalty is still -7 percent and not much smaller than the estimate obtained from Model D. We conclude that the health-earnings relationship is not explained by individuals in poor health working in other occupations, having lower educational attainments or skills, or having different marital statuses than healthy people.

\section{B. Global health - twins}

Our results for twins, focusing on global health without any controls, are displayed in Table 3. In order to sort out the potential influences of genetic and environmental factors, we separately ran the analysis DZ twins only, and on MZ twins only. We also report results for all twins pooled together.

\section{<Table 3 about here $>$}

First of all, the OLS regressions (Model A, C and E) indicate that these samples (all twins, DZ twins, and MZ twins) all seem representative of a larger population, as the results are similar to the OLS results in Table 2. Moreover, running specifications including twin fixed effects (Model B, D and F), estimates are reduced in similar magnitudes as previously observed for siblings. Even for MZ twins, the coefficient is similar to the one obtained exploiting variation 
between siblings. This suggests that non-twin siblings may be quite enough to draw relevant conclusions regarding the health-earnings relationship.

\section{Categories of conditions}

In Table 4, we show regression results for categories of health conditions. In addition to the specific categories of diagnoses, the table reports the effect of being diagnosed with any condition. Without controls, being diagnosed with any condition is estimated to reduce earnings by about 12 percent. When including sibling fixed effects, the coefficient is reduced to -7 percent, and controlling for cognitive and non-cognitive ability further reduces it to -3 percent. Again, the earnings is to the largest part driven by individuals in poor health earning lower incomes within the same occupations, within the same levels of schooling and within the same marital statuses compared to healthy people. This pattern also emerges for all significant categories of health conditions, and for all specific health diagnoses with significant effects (see below).

\section{$<$ Table 4 about here $>$}

In line with Currie et al. (2010), our results suggest that mental problems have more severe effects than any other types of conditions, that the effects of injuries is much smaller, and that congenital anomalies are even less important for young adult outcomes. ${ }^{19}$ According to Model B,

${ }^{19}$ Also, Case, Fertig and Paxson (2005) distinguished between physical conditions, mental conditions and "systems" conditions (e.g., respiratory; heart) when examining the effect on the 
which controls for sibling fixed effects, individuals with mental conditions earn on average 20 percent less, or according to Model $\mathrm{C}$ which also controls for schooling, these individuals earn about 18 percent less. As expected, the effect of mental conditions is reduced heavily (by about 60 percent) when controlling for cognitive and non-cognitive ability, and with full controls we find that mental conditions are associated with 6 percent lower earnings, which is still a very large effect. Next to mental problems, we find that the largest penalties are associated with endocrine/nutritional/metabolic conditions and with conditions of the nervous system. While having smaller effects, there is also clear statistical evidence that conditions of the sensory organs, respiratory conditions, and musculoskeletal conditions are associated with lower earnings.

Tumors and circulatory conditions stand out in that we find no significant effects of these, although one may argue that the inability to obtain significant effects of at least tumors might be due to the small number of observations; only 417 individuals are diagnosed with a tumor. At the same time, the coefficient estimates that we obtain for these conditions are small throughout so there is little evidence that they would be related to subsequent earnings. These findings are noteworthy because both circulatory conditions and cancer are the two most common causes of mortality in Sweden as well as in other industrialized countries (Socialstyrelsen, 2008; WHO, 2004), striking in particular individuals of lower socioeconomic status (e.g., Claussen et al., 2003; Ward et al., 2004).

number of "O-levels" passed by age 16. Like them, we find that the effects of mental problems tend to be several times as large as the effects of physical or system conditions. 
Congenital anomalies are of special interest because these by definition develop prior to birth, that is, long before schooling investment decisions, occupational choice, and before cognitive and other individual abilities have stabilized. ${ }^{20}$ The argument for controlling for such variables is thus weak in the case of congenital anomalies, as these variables may rather work as mediators. We conclude that the causal effect of congenital anomalies on earnings may be in the neighborhood of minus 5 percent, which is the estimate obtained when only sibling fixed effects are controlled for.

\section{Specific diagnoses}

Next, in Table 5, we show results for specific diagnoses. As before, controlling for schooling has little influence on the estimated health impact and the health penalties are also not explained by occupational or marital status. According to the results, alcoholism and drug dependence is the health problem affecting adult earnings the most. Without any controls, the estimated penalty is greater than 40 percent The penalty then falls to -29 percent when controls for sibling fixed effects are included (Model B), and further drops to -9 percent when the full set of controls are added. This effect is still twice as large as the effects of cognitive ability, noncognitive ability, or schooling (Model E). One should note that alcoholism and drug dependence is likely to develop late in adolescence, when IQ and other personal characteristics have mostly

${ }^{20}$ See Cunha et al. (2006) for an extensive discussion of critical periods in human ability formation. IQ, for example, appears to stabilize around age 10, whereas non-cognitive abilities may be malleable up until the early 20s. Hansen et al. (2004) document even in late adolescence, that IQ scores can be influenced by schooling. 
stabilized. The argument for controlling for cognitive and non-cognitive ability is thus quite strong in this case, suggesting that a reasonable estimate of the causal effect may be about 13 percent (Model D).

\section{$<$ Table 5 about here $>$}

Apart from alcoholism and drug dependence, large coefficients are also obtained for personality disorder, neurosis and diabetes. The negative effects of personality disorder and neurosis amount to more than 30 percent without any controls (Model A), more than 20 percent when sibling fixed effects have been included (Model B) and fall to about 7 percent when controls for ability, schooling, occupation and marital status are also added (Model E). Diabetes appears to be almost as severe as these mental problems, but gives imprecise estimates when

abilities are controlled for. ${ }^{21}$ Epilepsy also has negative effects, but these are somewhat smaller in magnitude.

Like Currie et al. (2010), we find no strong effects of asthma and it is statistically insignificant in several of the specifications. The same holds for migraine, hay fever and

${ }^{21}$ In contrast to all the other conditions we study, diabetes was essentially disqualifying from military service and diabetic individuals were typically not asked to undertake the cognitive and non-cognitive tests. We are thus not able to fully account for cognitive and non-cognitive ability among diabetics, and owing to the high correlation between diabetes and the indicators for missing values, estimates turn statistically insignificant. 
vertebrogenic pain syndrome. Throughout, these insignificant results cannot be blamed on too little variation in the data, as the confidence intervals are all quite tight around zero.

\section{E. Employment}

So far, we have shown that poor health during adolescence has a substantial impact on adult earnings. Next, we consider the possibility that poor health also affects labor supply. Using the same explanatory variables as before, we run linear probability models where the outcome variable is an indicator taking the value one if the individual was reported to have positive earnings in 2003. The results, displayed in Table 6-9, show a largely similar picture to those obtained for log earnings. Again, the strongest effects are found for mental conditions. Moreover, the devastating effects of poor mental health are even more pronounced in comparison to those of other types of conditions. Without controls, mental conditions are associated with a 16 percentage point lower probability of labor market participation, whereas with full controls the estimate is about five percentage points. Still, this is a very large effect given that the overall probability of not being employed in our data is only 8 percent. Conditions of the nervous system, which is the second most severe category of health problems in most of the models, is associated with a much more moderate penalty of minus four percentage points in the simplest model, an effect that then falls to only minus one percentage point with full controls.

\section{<Tables 6-9 about here>}

For specific conditions we again find alcoholism and drug dependence to be the most severe one, with a penalty of about minus 14 percentage points with full controls. Again, 
personality disorder, neurosis and diabetes have strong but clearly smaller effects than alcoholism and drug dependence. This time, however, personality disorder has clearly stronger effects than neurosis. Just as for the logarithm of earnings, we can establish that an unhealthy twin has a lower chance of participating on the labor market than his healthy twin brother. For MZ twins, we find a penalty of about minus four percentage points per ten steps of global health, a result that is significant at the 10 percent level. Again, this result strengthens the idea that our findings have a causal interpretation.

\section{$F$. Earnings with a threshold of SEK 100,000}

We then consider specifications where we only include individuals with earnings of at least SEK 100,000, corresponding to $\$ 10,188 .^{22}$ Antelius and Björklund (2000) have previously shown that if a threshold of SEK 100,000 is used when analyzing annual earnings based on Swedish tax records, one receives a return to education that is similar to the one obtained when analyzing real wages per hour. While it is not entirely clear to what extent this result can be extrapolated to the case of returns to health, we expect to obtain results that more closely resemble the effect of health on hourly wages when imposing this earnings restriction.

Tables A3 to A6 show our results when imposing the restriction. On the whole, coefficients fall by about a half in specifications not controlling for ability. Accounting for differences inabilities, however, the effect becomes much smaller. With full controls, for example, an increase in bad global health by ten steps implies only 1.5 percent lower earnings. This stands in

${ }^{22}$ This was calculated by dividing SEK 100,000 by the 2003 PPP exchange rate for private consumption provided by the OECD. 
stark contrast to the penalty of -7 percent obtained without the earnings restriction. The penalty for mental health problems is now only -0.8 percent when full controls are included and it is barely statistically significant, suggesting that the severely negative effects of mental health problems on labor market outcomes may be almost exclusively driven by employment and not by wages. In fact, conditions of the nervous system now have more detrimental effects than mental ones as they, with full controls, result in 2.3 percent lower earnings when imposing the restriction.

Overall, our results suggest that the earnings penalty for bad health to an important extent is driven by hours worked. This could reflect that males with poor adolescent health are more likely to work part-time, are more likely to be unemployed part of the year, are more likely to be on sick leave, or are more likely to away from work because of occupational injuries. In the next section, we throw further light on these possibilities by asking what share of an individual's total income is made up of sickness-related benefits.

\section{G. Benefits}

Tables A7-A10 explore the effects of adolescent health on welfare benefits received in 2003. Our measure of benefits represents the sum of incomes from "taxable income related to sick pay". ${ }^{23}$ Since these benefits are typically related to labor market earnings, we define our outcome variable as benefits as a share of total income (benefits plus earnings).

${ }^{23}$ Specifically, this includes income from sickness benefit, disease carrier's allowance, sick pay guarantee (a compensation that can be paid to an employee engaged in a dispute with his 
Qualitatively, our results for benefits are similar to those for earnings. Estimates are substantially reduced when controlling for sibling fixed effects and abilities, but controlling for education, occupation and marital status makes essentially no difference, suggesting that these factors do not importantly mediate the relationships between health and the uptake of benefits. Quantitatively, the effect on the benefit share is remarkably small; a ten step increase in bad global health is associated with only a four percentage point larger benefit share, and with controls for ability this effect reduces to less than two percentage points. Among twins, the effects are strongly statistically significant both in the population of all twins and among MZ twins, and there is no evidence that effects would be smaller when comparing twins than when comparing siblings in general.

For categories and types of health conditions, we again find the largest effects resulting from mental problems. In particular, with full controls, mental conditions are on average associated with a two percentage point higher benefit share. The effects of neurosis and personality disorder are of similar magnitudes, whereas, as in our main results for earnings, the penalty for alcoholism and drug dependence is larger. While being much smaller in magnitudes, there is also statistical evidence that the groups of respiratory conditions, digestive conditions, musculoskeletal conditions and injuries are associated with greater benefit take-up, as well as the condition of vertebrogenic pain syndrome. We conclude that individuals that suffer from these conditions at the age of 18 may fare worse in the labor market in adulthood partly because they are more prone to being absent from work due to sickness.

employer when sick), occupational injury allowance, parental allowance at childbirth or adoption, and allowances for taking care of a sick child or relative. 


\section{Conclusion}

We contribute to the small literature on the relationship between adolescent health and adult labor market outcomes by using a unique dataset that covers almost the entire population of Swedish males born between 1950 and 1970. Our study confirms that health at the doorstep of adulthood has strong effects on later outcomes, and we document that this relationship can partly - but only partly - be explained be differences in cognitive and non-cognitive abilities. Controlling for schooling, occupation and marital status has little effect on the penalties of poor health, however, and we conclude that these factors do not appear to act as important mediators of the relationship between health and subsequent earnings, employment, wages, or benefit takeup.

In addition to siblings, our study examines subsamples of twins in an attempt to additionally control for unobserved characteristics. While these estimates are more uncertain due to the limited number of observations, they do suggest that global health is negatively related to later earnings. It is reassuring that the penalty for global health is of about the same size in our models with twin fixed effects as in our models with sibling fixed effects, since this lends credibility to our sibling-based estimates in general.

Due to data availability, previous research regarding the long-term effects of health status early in life has in general only used unidimensional health measures such as birth weight or retrospectively self-reported global health. As a major contribution of this paper, we conduct an analysis of a large number of broad categories of health conditions, as well as more narrow classes. This analysis shows that while most categories of diseases may have important long-run effects, the strongest ones are detected for mental ones. Mental problems also have much stronger 
effects on employment and benefit up-take than any other category of conditions, pointing to mechanisms such as sickness absence or inability to find a job. To increase opportunities for adolescents with mental conditions, research has to further explore the mechanisms through which these problems determine subsequent outcomes. 


\section{References}

Almond, Douglas, and Janet Currie. 2011. "Human Capital Development Before Age Five.” In Handbook of Labor Economics, Vol 4, ed. Orley Ashenfelter, and David Card. Amsterdam, Netherlands: North Holland.

Antelius, Jesper, and Anders Björklund. 2000. "How Reliable are Register Data for Studies of the Return on Schooling? An Examination of Swedish Data." Scandinavian Journal of Educational Research, 44(4):341-55.

Andersson, Jens, and Berit Carlstedt. 2003. Urval till Plikttjänst. ILM Serie T:28. Karlstad, Sweden: Institutionen för ledarskap och management, Försvarshögskolan.

d'Uva, Teresa Bago, Owen O’Donnell, and van Doorslaer, Eddy. 2008. "Differential Health Reporting by Education Level and its Impact on the Measurement of Health Inequalities Among Older Europeans.” International Journal of Epidemiology, 37(6):1375-83.

Behrman, Jere R., and Mark R. Rosenzweig. 2004. "Returns to Birth Weight." Review of Economics and Statistics. 86(2):586-601.

Bharadwaj, Prashant, Juan Eberhard, and Christopher Neilson. 2013. "Health at Birth, Parental Investments and Academic Outcomes." University of California at San Diego Working Paper Series.

Black, Sandra E., Paul J.Devereux, and Kjell G. Salvanes. 2007. "From the Cradle to the Labor Market? The Effect of Birth Weight on Adult Outcomes." Quarterly Journal of Economics, 122(1):409-39.

Case, Anne, Angela Fertig, and Christina Paxson. 2005. "The Lasting Impact of Childhood Health and Circumstance." Journal of Health Economics, 24(2):365-89.

Case, Anne, Darren Lubotsky, and Christina Paxson. 2002. "Economic Status and Health in Childhood: The Origins of the Gradient." American Economic Review 92(5): 1308-34. 
Case, Anne, and Christina Paxson. 2008. "Height, Health, and Cognitive Function at Older Ages." American Economic Review, 98(2):463-7.

Claussen, Bjorgulf, G Davey Smith, and Dag Thelle. 2003. "Impact of Childhood and Adulthood Socioeconomic Position on Cause Specific Mortality: The Oslo Mortality Study.” Journal of Epidemiology and Community Health, 57(1):40-5.

Collins, John Gary. 1993. "Prevalence of Selected Chronic Conditions: United States, 1986-88." Data From the National Health Survey, 10(182).

Cunha, Flavio, James J. Heckman, and Lance Lochner. 2006. "Interpreting the Evidence on LifeCycle Ability Formation.” In Handbook of the Economics of Education, Vol. 1, ed. Erik Hanushek, and Finis Welch. Amsterdam, Netherlands: North Holland.

Currie, Janet. 2009. "Healthy, Wealthy, and Wise: Socioeconomic Status, Poor Health in Childhood, and Human Capital Development." Journal of Economic Literature, 47 (1):87-122.

Currie, Janet, and Rosemary Hyson. 1999. "Is the Impact of Health Shocks Cushioned by Socioeconomic Status? The Case of Low Birthweight.” American Economic Review, 89(2):24550.

Currie, Janet, Mark Stabile, Phongsack Manivong, and Leslie L. Roos. 2010. "Child Health and Young Adult Outcomes." Journal of Human Resources, 45(3):517-48.

Ettner, Susan L., Richard G. Frank, and Ronald C. Kessler. 1997. “The Impact of Psychiatric Disorders on Labor Market Outcomes." Industrial and Labor Relations Review, 51(1):64-81.

Ettner, Susan L., Johanna Catherine Maclean, and Michael T. French. 2011. "Does Having a Dysfunctional Personality Hurt Your Career? Axis II Personality Disorders and Labor Market Outcomes." Industrial Relations: A Journal of Economy and Society, 50(1):149-73.

Famulari, Melissa. 1992. "The Effects of a Disability on Labor Market Performance: The Case of Epilepsy.” Southern Economic Journal, 58(4):1072-87.

Fanning, Desmond. 1981. "Ill Health Retirement as an Indicator of Morbidity." Journal of the Society of Occupational Medicine, 31(3):103-11. 
Ferrari, Michel D. 1998. "The Economic Burden of Migraine to Society.” Pharmacoeconomics, 13(6):667-76.

Figlio, David N., Jonathan Guryan, Krzysztof Karbownik, and Jeffrey Roth. 2013. "The Effects of Poor Neonatal Health on Children's Cognitive Development." NBER Working Paper 18846.

Fletcher, Jason M., and Steven F. Lehrer. 2009. "Using Genetic Lotteries within Families to Examine the Causal Impact of Poor Health on Academic Achievement.” Working Paper No. 15148, National Bureau of Economic Research.

Krahn, Murray D., Catherine Berka, Peter Langois, and Allan Detsky. 1996. "Direct and Indirect Costs of Asthma in Canada." Canadian Medical Association Journal, 154(6):821-54.

Lichtenstein, Paul, Patrick F. Sullivan, Sven Cnattingius, Margaret Gatz, Sofie Johansson, Eva Carlström, Camilla Björk, Magnus Svartengren, Alicja Volk, Lars Klareskog, Ulf de

Faire, Martin Schalling, Juni Palmgren, and Nancy L. Pedersen. 2006. "The Swedish Twin Registry in the Third Millennium: An Update." Twin Research and Human Genetics, 9(6):87582.

Hansen, Karsten T, James J. Heckman, and Kathleen J. Mullen. 2004. ’The Effect of Schooling and Ability on Achievement Test Scores." Journal of Econometrics, 121(1-2): 39-98.

Heckman, James J., and Yona Rubinstein. 2001. "The Importance of Noncognitive Skills: Lessons from the GED Testing Program." American Economic Review, 91(2): 145-49. Lindeboom, Maarten, and Marcel Kerkhofs. 2009. "Health and Work of the Elderly: Subjective Health Measures, Reporting Errors and Endogeneity in the Relationship Between Health and Work." Journal of Applied Econometrics, 24(6):1024-46.

Lindqvist, Erik, and Roine Vestman. 2011. "The Labor Market Returns to Cognitive and Noncognitive Ability: Evidence from the Swedish Enlistment." American Economic Journal: Applied Economics, 3(1):101-28. 
Lundborg, Petter, Anton Nilsson, and Dan-Olof Rooth. 2014a. "Does Early Life Health Predict Schooling Within Twin Pairs?” In Nilsson, Anton: Health, Skills and Labor Market Success (Doctoral dissertation), Lund University, Lund, Sweden.

Lundborg, Petter, Anton Nilsson, and Dan-Olof Rooth. 2014b. "Parental Education and Offspring Outcomes: Evidence from the Swedish Compulsory School Reform.” American Economic Journal: Applied Economics, 6(1):253-78.

Lundborg, Petter, Paul Nystedt, and Dan-Olof Rooth. 2013. "Height and Earnings. The Role of Cognitive and Non-cognitive Skills.” Forthcoming in Journal of Human Resources.

Malone, Daniel C., Kenneth A. Lawson, David H. Smith, H. Michael Arrighi, and Carmelina Battista. 1997. "A Cost of Illness Study of Allergic Rhinitis in the United States." Journal of Allergy and Clinical Immunology, 99(1):22-7.

McGarry. 2004. "Health and Retirement: Do Changes in Health Affect Retirement Expectations?" Journal of Human Resources, 39(3):624-648.

Ng, Ying Chu, Philip Jacobs, and Jeffrey A. Johnson. 2001. "Productivity Losses Associated with Diabetes in the U.S.” Diabetes Care, 24(2):257-61.

Olsen, Todd L., Robyn L. Anderson, Stephen R. Dearwater, Andrea M. Kriska, Jane A. Cauley, Deborah J. Aaron, and Ronald E. LaPorte. 1992. "The Epidemiology of Low Back Pain in an Adolescent Population.” American Journal of Public Health, 82(4): 606-8.

Royer, Heather. 2009. "Separated at Girth: US Twin Estimates of the Effects of Birth Weight." American Economic Journal: Applied Economics, 1(1):49-85.

Salm, Martin, and Daniel Schunk. 2012. "The Relationship Between Child Health, Developmental Gaps, and Parental Education: Evidence from Administrative Data." Journal of the European Economic Association, 10(6):1425-49.

Smith, James P. 2009. "The Impact of Childhood Health on Adult Labor Market Outcomes." Review of Economics and Statistics, 91(3):478-89.

Socialstyrelsen. 2008. Dödsorsaker 2008. Stockholm, Sweden. 
Ward, Elizabeth, Ahmedin Jemal, Vilma Cokkinides, Gopal K. Singh, Cheryll Cardinez, Asma Ghafoor, and Michael Thun. 2004. "Cancer Disparities by Race/Ethnicity and Socioeconomic Status." CA: A Cancer Journal for Clinicians, 54(2):78-93.

WHO. 1967. Manual of the international statistical classification of diseases, injuries, and causes of death, eight revision. Geneva, Switzerland.

WHO. 2004. The World Health Report 2004. Geneva, Switzerland. 


\section{Tables}

Table 1: Descriptive statistics.

\begin{tabular}{lcc}
\hline Non-binary variables & Mean (std) & Missing observations \\
\hline (Log) earnings & $12.392(0.812)$ & - \\
Global health & $2.035(3.691)$ & - \\
Years of schooling & $11.827(2.233)$ & 258 \\
Cognitive ability & $5.140(1.931)$ & 2,840 \\
Non-cognitive ability & $5.146(1.708)$ & 6,381 \\
\hline Binary variables & Mean & Prevalence \\
\hline Any diagnose & 0.490 & 135,137 \\
Tumors & 0.002 & 417 \\
Endocrine etc. & 0.014 & 3,873 \\
Mental & 0.064 & 17,558 \\
Nervous & 0.014 & 3,920 \\
Sensory & 0.156 & 42,910 \\
Circulatory & 0.026 & 7,221 \\
Respiratory & 0.107 & 29,573 \\
Digestive & 0.030 & 8,397 \\
Genito-urinary & 0.013 & 3,623 \\
Skin & 0.052 & 14,377 \\
Musculoskeletal etc. & 0.135 & 37,129 \\
Congenital anomalies & 0.016 & 4,417 \\
Injuries & 0.047 & 12,879 \\
Diabetes & 0.002 & 528 \\
Neurosis & 0.027 & 7,479 \\
Personality disorder & 0.008 & 2,243 \\
Alcoholism and drug dependence & 0.005 & 1,289 \\
Epilepsy & 0.004 & 998 \\
Migraine & 0.009 & 2,410 \\
Asthma & 0.024 & 6,705 \\
Hay fever & 0.066 & 18,073 \\
Vertebrogenic pain syndrome & 0.056 & 15,391 \\
\hline No. of observations & & \\
\hline Notes & 275,534 & \\
\hline
\end{tabular}

Notes: The table shows descriptive statistics before the standardization of control variables. 
Table 2. The earnings penalty for Global health. Men born 1950-1970. Logarithm of annual earnings in 2003.

\begin{tabular}{|c|c|c|c|c|c|}
\hline Variable & (A) & (B) & (C) & (D) & $(\mathrm{E})$ \\
\hline Global health $(* 10)$ & $\begin{array}{c}-0.252 * * * \\
(0.005)\end{array}$ & $\begin{array}{c}-0.175 * * * \\
(0.006)\end{array}$ & $\begin{array}{c}-0.156 * * * \\
(0.006)\end{array}$ & $\begin{array}{c}-0.082 * * * \\
(0.007)\end{array}$ & $\begin{array}{c}-0.073 * * * \\
(0.006)\end{array}$ \\
\hline Schooling: & & & $\begin{array}{c}0.148^{* * *} \\
(0.003)\end{array}$ & & $\begin{array}{c}0.051 * * * \\
(0.003)\end{array}$ \\
\hline Cognitive ability: & & & & $\begin{array}{c}0.110^{* * *} \\
(0.003)\end{array}$ & $\begin{array}{c}0.036 * * * \\
(0.003)\end{array}$ \\
\hline Non-cognitive ability: & & & & $\begin{array}{c}0.077 * * * \\
(0.003)\end{array}$ & $\begin{array}{c}0.047 * * * \\
(0.003)\end{array}$ \\
\hline Sibling fixed effects & No & Yes & Yes & Yes & Yes \\
\hline Occupation fixed effects & No & No & No & No & Yes \\
\hline Controls for marital status & No & No & No & No & Yes \\
\hline $\mathrm{R} 2$ & 0.015 & 0.009 & 0.030 & 0.030 & 0.160 \\
\hline No. of observations & & & 275,534 & & \\
\hline \multicolumn{6}{|c|}{$\begin{array}{l}\text { Notes: Columns B through E report estimates from the regression model: } \log \operatorname{Earnings}_{i j}=a+b^{*} G H_{i j}+c^{*} X_{i j}+f_{j}+ \\
e_{i j} \text {. Model A contains GH and age fixed effects and is estimated using OLS. All regressions were run using robust } \\
\text { standard errors. Fixed effects for birth cohort were included. * indicates significance at the } 10 \text { percent level, } * * \\
\text { indicates significance at the } 5 \text { percent level, and } * * * \text { indicates significance at the } 1 \text { percent level. In sibling fixed } \\
\text { effects models, R2 refers to the within-siblings R2. }\end{array}$} \\
\hline
\end{tabular}


Table 3: The earnings penalty for Global health. Men born 1950-1970. Logarithm of annual earnings in 2003. Twins.

\begin{tabular}{|c|c|c|c|c|c|c|}
\hline Variable & $(\mathrm{A})$ & (B) & (C) & (D) & $(\mathrm{E})$ & $(\mathrm{F})$ \\
\hline Global health(*10) & $\begin{array}{c}-0.200 * * * \\
(0.026)\end{array}$ & $\begin{array}{c}-0.114 * * * \\
(0.042)\end{array}$ & $\begin{array}{c}-0.176 * * * \\
(0.036)\end{array}$ & $\begin{array}{c}-0.154 * * * \\
(0.053)\end{array}$ & $\begin{array}{c}-0.161 * * * \\
(0.047)\end{array}$ & $\begin{array}{c}-0.131 * \\
(0.077)\end{array}$ \\
\hline Type of twin & All & All & $\mathrm{DZ}$ & $\mathrm{DZ}$ & $\mathrm{MZ}$ & $\mathrm{MZ}$ \\
\hline Twin fixed effects & No & Yes & No & Yes & No & Yes \\
\hline $\mathrm{R} 2$ & 0.009 & 0.002 & 0.008 & 0.006 & 0.005 & 0.003 \\
\hline No. of observations & 6,478 & 6,478 & 3,024 & 3,024 & 2,232 & 2,232 \\
\hline
\end{tabular}


Table 4. The earnings penalty for Broad categories of health conditions. Men born 1950-1970.

Logarithm of annual earnings in 2003.

\begin{tabular}{|c|c|c|c|c|c|}
\hline Variable & (A) & (B) & (C) & (D) & (E) \\
\hline Diagnose $=1$ : & $\begin{array}{c}-0.118 * * * \\
(0.003)\end{array}$ & $\begin{array}{c}-0.070 * * * \\
(0.004)\end{array}$ & $\begin{array}{c}-0.060 * * * \\
(0.004)\end{array}$ & $\begin{array}{c}-0.030 * * * \\
(0.004)\end{array}$ & $\begin{array}{c}-0.025 * * * \\
(0.004)\end{array}$ \\
\hline \multicolumn{6}{|l|}{ By type: } \\
\hline Tumors & $\begin{array}{c}0.015 \\
(0.035)\end{array}$ & $\begin{array}{l}-0.024 \\
(0.046)\end{array}$ & $\begin{array}{l}-0.015 \\
(0.046)\end{array}$ & $\begin{array}{c}0.002 \\
(0.048)\end{array}$ & $\begin{array}{c}0.018 \\
(0.045)\end{array}$ \\
\hline Endocrine etc. & $\begin{array}{c}-0.181 * * * \\
(0.015)\end{array}$ & $\begin{array}{c}-0.109 * * * \\
(0.019)\end{array}$ & $\begin{array}{c}-0.095^{* * *} \\
(0.019)\end{array}$ & $\begin{array}{c}-0.075^{* * *} \\
(0.020)\end{array}$ & $\begin{array}{c}-0.058 * * * \\
(0.019)\end{array}$ \\
\hline Mental & $\begin{array}{c}-0.315^{* * *} \\
(0.008)\end{array}$ & $\begin{array}{c}-0.202 * * * \\
(0.010)\end{array}$ & $\begin{array}{c}-0.176^{* * *} \\
(0.010)\end{array}$ & $\begin{array}{c}-0.069 * * * \\
(0.011)\end{array}$ & $\begin{array}{c}-0.064 * * * \\
(0.010)\end{array}$ \\
\hline Nervous system & $\begin{array}{c}-0.112 * * * \\
(0.014)\end{array}$ & $\begin{array}{c}-0.087 * * * \\
(0.018)\end{array}$ & $\begin{array}{c}-0.080^{* * * *} \\
(0.018)\end{array}$ & $\begin{array}{l}-0.030 \\
(0.019)\end{array}$ & $\begin{array}{l}-0.031 * \\
(0.018)\end{array}$ \\
\hline Sensory organs & $\begin{array}{c}-0.057 * * * \\
(0.004)\end{array}$ & $\begin{array}{c}-0.033 * * * \\
(0.006)\end{array}$ & $\begin{array}{c}-0.031 * * * \\
(0.006)\end{array}$ & $\begin{array}{c}-0.021 * * * \\
(0.006)\end{array}$ & $\begin{array}{c}-0.015 * * * \\
(0.005)\end{array}$ \\
\hline Circulatory & $\begin{array}{c}0.003 \\
(0.010)\end{array}$ & $\begin{array}{c}0.011 \\
(0.013)\end{array}$ & $\begin{array}{c}0.012 \\
(0.012)\end{array}$ & $\begin{array}{c}0.010 \\
(0.012)\end{array}$ & $\begin{array}{c}0.009 \\
(0.012)\end{array}$ \\
\hline Respiratory & $\begin{array}{c}0.008 \\
(0.005)\end{array}$ & $\begin{array}{c}-0.017 * * \\
(0.007)\end{array}$ & $\begin{array}{c}-0.018^{* * *} \\
(0.007)\end{array}$ & $\begin{array}{l}-0.012 * \\
(0.007)\end{array}$ & $\begin{array}{c}-0.018 * * * \\
(0.006)\end{array}$ \\
\hline Digestive & $\begin{array}{c}-0.044 * * * \\
(0.009)\end{array}$ & $\begin{array}{l}-0.010 \\
(0.012)\end{array}$ & $\begin{array}{l}-0.007 \\
(0.012)\end{array}$ & $\begin{array}{l}-0.003 \\
(0.012)\end{array}$ & $\begin{array}{c}0.001 \\
(0.012)\end{array}$ \\
\hline Genito-urinary & $\begin{array}{c}-0.040 * * * \\
(0.014)\end{array}$ & $\begin{array}{l}-0.029^{*} \\
(0.018)\end{array}$ & $\begin{array}{l}-0.028 \\
(0.018)\end{array}$ & $\begin{array}{l}-0.027 \\
(0.018)\end{array}$ & $\begin{array}{l}-0.026 \\
(0.016)\end{array}$ \\
\hline Skin & $\begin{array}{l}-0.010 \\
(0.007)\end{array}$ & $\begin{array}{l}-0.016^{*} \\
(0.009)\end{array}$ & $\begin{array}{l}-0.013 \\
(0.009)\end{array}$ & $\begin{array}{c}-0.012 \\
(0.009)\end{array}$ & $\begin{array}{l}-0.005 \\
(0.009)\end{array}$ \\
\hline Musculoskeletal etc. & $\begin{array}{c}-0.067 * * * \\
(0.005)\end{array}$ & $\begin{array}{c}-0.024 * * * \\
(0.006)\end{array}$ & $\begin{array}{c}-0.016^{* *} \\
(0.006)\end{array}$ & $\begin{array}{l}-0.010^{*} \\
(0.006)\end{array}$ & $\begin{array}{l}-0.007 \\
(0.006)\end{array}$ \\
\hline Congenital anomalies & $\begin{array}{l}-0.022^{*} \\
(0.012)\end{array}$ & $\begin{array}{c}-0.046^{* * * *} \\
(0.015)\end{array}$ & $\begin{array}{c}-0.043 * * * \\
(0.015)\end{array}$ & $\begin{array}{l}-0.014 \\
(0.015)\end{array}$ & $\begin{array}{l}-0.020 \\
(0.014)\end{array}$ \\
\hline Injuries & $\begin{array}{c}-0.045 * * * \\
(0.008)\end{array}$ & $\begin{array}{c}-0.040 * * * \\
(0.010)\end{array}$ & $\begin{array}{c}-0.033 * * * \\
(0.010)\end{array}$ & $\begin{array}{c}-0.031 * * * \\
(0.010)\end{array}$ & $\begin{array}{c}-0.025 * * * \\
(0.009)\end{array}$ \\
\hline Schooling & & & $\begin{array}{c}0.148 * * * \\
(0.003)\end{array}$ & & $\begin{array}{c}0.050 * * * \\
(0.003)\end{array}$ \\
\hline Cognitive ability & & & & $\begin{array}{c}0.110 * * * \\
(0.003)\end{array}$ & $\begin{array}{c}0.037 * * * \\
(0.003)\end{array}$ \\
\hline Non-cognitive ability & & & & $\begin{array}{c}0.077 * * * \\
(0.003)\end{array}$ & $\begin{array}{c}0.048^{* * *} \\
(0.003)\end{array}$ \\
\hline Sibling fixed effects & No & Yes & Yes & Yes & Yes \\
\hline Occupation fixed effects & No & No & No & No & Yes \\
\hline Controls for marital status & No & No & No & No & Yes \\
\hline R-squared & 0.017 & 0.008 & 0.030 & 0.030 & 0.161 \\
\hline No. of observations & & & 275,534 & & \\
\hline
\end{tabular}


Table 5. The earnings penalty for Specific health conditions. Men born 1950-1970. Logarithm of annual earnings in 2003.

\begin{tabular}{|c|c|c|c|c|c|}
\hline Variable & (A) & (B) & $(\mathrm{C})$ & (D) & (E) \\
\hline Diabetes & $\begin{array}{c}-0.243 * * * \\
(0.046)\end{array}$ & $\begin{array}{c}-0.208 * * * \\
(0.058)\end{array}$ & $\begin{array}{c}-0.198 * * * \\
(0.057)\end{array}$ & $\begin{array}{l}-0.154 \\
(0.125)\end{array}$ & $\begin{array}{l}-0.162 \\
(0.118)\end{array}$ \\
\hline Neurosis & $\begin{array}{c}-0.328 * * * \\
(0.012)\end{array}$ & $\begin{array}{c}-0.223 * * * \\
(0.016)\end{array}$ & $\begin{array}{c}-0.199 * * * \\
(0.016)\end{array}$ & $\begin{array}{c}-0.098 * * * \\
(0.016)\end{array}$ & $\begin{array}{c}-0.091 * * * \\
(0.015)\end{array}$ \\
\hline Personality disorder & $\begin{array}{c}-0.354 * * * \\
(0.023)\end{array}$ & $\begin{array}{c}-0.207 * * * \\
(0.028)\end{array}$ & $\begin{array}{c}-0.182 * * * \\
(0.028)\end{array}$ & $\begin{array}{c}-0.073 * * * \\
(0.028)\end{array}$ & $\begin{array}{c}-0.057 * * \\
(0.026)\end{array}$ \\
\hline Alcoholism and drug dependence & $\begin{array}{c}-0.443 * * * \\
(0.032)\end{array}$ & $\begin{array}{c}-0.288 * * * \\
(0.040)\end{array}$ & $\begin{array}{c}-0.260 * * * \\
(0.040)\end{array}$ & $\begin{array}{c}-0.132 * * * \\
(0.040)\end{array}$ & $\begin{array}{c}-0.094 * * \\
(0.038)\end{array}$ \\
\hline Epilepsy & $\begin{array}{c}-0.185 * * * \\
(0.030)\end{array}$ & $\begin{array}{c}-0.167 * * * \\
(0.039)\end{array}$ & $\begin{array}{c}-0.155^{* * *} * \\
(0.038)\end{array}$ & $\begin{array}{l}-0.062 \\
(0.041)\end{array}$ & $\begin{array}{l}-0.071 * \\
(0.039)\end{array}$ \\
\hline Migraine & $\begin{array}{c}-0.067 * * * \\
(0.017)\end{array}$ & $\begin{array}{l}-0.025 \\
(0.023)\end{array}$ & $\begin{array}{l}-0.021 \\
(0.023)\end{array}$ & $\begin{array}{l}-0.018 \\
(0.023)\end{array}$ & $\begin{array}{l}-0.016 \\
(0.022)\end{array}$ \\
\hline Asthma & $\begin{array}{c}-0.034 * * * \\
(0.010)\end{array}$ & $\begin{array}{l}-0.023 * \\
(0.014)\end{array}$ & $\begin{array}{l}-0.022 \\
(0.014)\end{array}$ & $\begin{array}{l}-0.007 \\
(0.014)\end{array}$ & $\begin{array}{l}-0.024 * \\
(0.013)\end{array}$ \\
\hline Hay fever & $\begin{array}{c}0.041 * * * \\
(0.006)\end{array}$ & $\begin{array}{l}-0.010 \\
(0.008)\end{array}$ & $\begin{array}{l}-0.013 \\
(0.008)\end{array}$ & $\begin{array}{l}-0.013 \\
(0.008)\end{array}$ & $\begin{array}{l}-0.015^{*} \\
(0.008)\end{array}$ \\
\hline Vertebrogenic pain syndrome & $\begin{array}{c}-0.100 * * * \\
(0.007)\end{array}$ & $\begin{array}{c}-0.025 * * * \\
(0.009)\end{array}$ & $\begin{array}{c}-0.014 \\
(0.009)\end{array}$ & $\begin{array}{l}-0.003 \\
(0.009)\end{array}$ & $\begin{array}{l}-0.003 \\
(0.009)\end{array}$ \\
\hline Schooling & & & $\begin{array}{c}0.149 * * * \\
(0.003)\end{array}$ & & $\begin{array}{c}0.051 * * * \\
(0.003)\end{array}$ \\
\hline Cognitive ability & & & & $\begin{array}{c}0.110 * * * \\
(0.003)\end{array}$ & $\begin{array}{c}0.037 * * * \\
(0.003)\end{array}$ \\
\hline Non-cognitive ability & & & & $\begin{array}{c}0.078 * * * \\
(0.003)\end{array}$ & $\begin{array}{c}0.048 * * * \\
(0.003)\end{array}$ \\
\hline Sibling fixed effects & No & Yes & Yes & Yes & Yes \\
\hline Occupation fixed effects & No & No & No & No & Yes \\
\hline Controls for marital status & No & No & No & No & Yes \\
\hline R-squared & 0.015 & 0.008 & 0.029 & 0.030 & 0.160 \\
\hline No. of observations & & & 275,534 & & \\
\hline
\end{tabular}


Table 6. Employment. The penalty for Global health. Men born 1950-1970.

\begin{tabular}{|c|c|c|c|c|c|}
\hline Variable & $(\mathrm{A})$ & (B) & $(\mathrm{C})$ & (D) & $(\mathrm{E})$ \\
\hline Global health(*10) & $\begin{array}{c}-0.110 * * * \\
(0.002)\end{array}$ & $\begin{array}{c}-0.082 * * * \\
(0.002)\end{array}$ & $\begin{array}{c}-0.074 * * * \\
(0.002)\end{array}$ & $\begin{array}{c}-0.042 * * * \\
(0.002)\end{array}$ & $\begin{array}{c}-0.038 * * * \\
(0.002)\end{array}$ \\
\hline Schooling: & & & $\begin{array}{c}0.021 * * * \\
(0.001)\end{array}$ & & $\begin{array}{c}0.013 * * * \\
(0.001)\end{array}$ \\
\hline Cognitive ability: & & & & $\begin{array}{c}0.016^{* * *} \\
(0.001)\end{array}$ & $\begin{array}{c}0.011^{* * *} \\
(0.001)\end{array}$ \\
\hline Non-cognitive ability: & & & & $\begin{array}{c}0.018 * * * \\
(0.001)\end{array}$ & $\begin{array}{c}0.015^{* * * *} \\
(0.001)\end{array}$ \\
\hline Sibling fixed effects & No & Yes & Yes & Yes & Yes \\
\hline Occupation fixed effects & No & No & No & No & Yes \\
\hline Controls for marital status & No & No & No & No & Yes \\
\hline R2 & 0.026 & 0.014 & 0.114 & 0.027 & 0.156 \\
\hline No. of observations & & & 319,145 & & \\
\hline
\end{tabular}


Table 7: Employment. The penalty for Global health. Men born 1950-1970. Twins.

\begin{tabular}{lcccccc}
\hline Variable & $(\mathrm{A})$ & $(\mathrm{B})$ & $(\mathrm{C})$ & $(\mathrm{D})$ & $(\mathrm{E})$ & $(\mathrm{F})$ \\
\hline & & & & & & \\
Global health(*10) & $-0.111^{* * *}$ & $-0.064^{* * *}$ & $-0.086^{* * *}$ & $-0.053^{* * *}$ & $-0.093^{* * *}$ & $-0.035^{*}$ \\
& $(0.008)$ & $(0.012)$ & $(0.011)$ & $(0.017)$ & $(0.013)$ & $(0.021)$ \\
Type of twin & $\mathrm{All}$ & $\mathrm{All}$ & $\mathrm{DZ}$ & $\mathrm{DZ}$ & $\mathrm{MZ}$ & $\mathrm{MZ}$ \\
\hline Twin fixed effects & No & Yes & No & Yes & No & Yes \\
\hline R2 & 0.026 & 0.007 & 0.016 & 0.006 & 0.020 & 0.002 \\
\hline No. of observations & 7,502 & 7,502 & 3,476 & 3,476 & 2,496 & 2,496 \\
\hline
\end{tabular}

Notes: The above models contain GH and no controls. * indicates significance at the 10 percent level, ** indicates significance at the 5 percent level, and $* * *$ indicates significance at the 1 percent level. In twin fixed effects models, $\mathrm{R} 2$ refers to the within-twins $\mathrm{R} 2$. 
Table 8. Employment. The penalty for Broad categories of health conditions. Men born 19501970.

\begin{tabular}{|c|c|c|c|c|c|}
\hline Variable & (A) & (B) & $(\mathrm{C})$ & (D) & $(\mathrm{E})$ \\
\hline Diagnose $=1:$ & $\begin{array}{c}-0.037 * * * \\
(0.001)\end{array}$ & $\begin{array}{c}-0.025 * * * \\
(0.001)\end{array}$ & $\begin{array}{c}-0.022 * * * \\
(0.001)\end{array}$ & $\begin{array}{c}-0.009 * * * \\
(0.001)\end{array}$ & $\begin{array}{c}-0.009 * * * \\
(0.001)\end{array}$ \\
\hline \multicolumn{6}{|l|}{ By type: } \\
\hline Tumors & $\begin{array}{c}-0.038 * * * \\
(0.014)\end{array}$ & $\begin{array}{c}-0.039 * * \\
(0.018)\end{array}$ & $\begin{array}{c}-0.035^{* *} \\
(0.018)\end{array}$ & $\begin{array}{c}-0.027 \\
(0.018)\end{array}$ & $\begin{array}{c}-0.021 \\
(0.018)\end{array}$ \\
\hline Endocrine etc. & $\begin{array}{c}-0.031 * * * \\
(0.005)\end{array}$ & $\begin{array}{c}-0.031 * * * \\
(0.006)\end{array}$ & $\begin{array}{c}-0.024 * * * \\
(0.006)\end{array}$ & $\begin{array}{c}-0.019 * * * \\
(0.007)\end{array}$ & $\begin{array}{l}-0.012 * \\
(0.006)\end{array}$ \\
\hline Mental & $\begin{array}{c}-0.155^{* * *} \\
(0.003)\end{array}$ & $\begin{array}{c}-0.112 * * * \\
(0.003)\end{array}$ & $\begin{array}{c}-0.101 * * * \\
(0.003)\end{array}$ & $\begin{array}{c}-0.058 * * * \\
(0.004)\end{array}$ & $\begin{array}{c}-0.053 * * * \\
(0.003)\end{array}$ \\
\hline Nervous system & $\begin{array}{c}-0.040 * * * \\
(0.005)\end{array}$ & $\begin{array}{c}-0.042 * * * \\
(0.006)\end{array}$ & $\begin{array}{c}-0.038 * * * \\
(0.006)\end{array}$ & $\begin{array}{c}-0.013^{* *} \\
(0.006)\end{array}$ & $\begin{array}{c}-0.014 * * \\
(0.006)\end{array}$ \\
\hline Sensory organs & $\begin{array}{c}-0.005 * * * \\
(0.001)\end{array}$ & $\begin{array}{c}0.000 \\
(0.002)\end{array}$ & $\begin{array}{c}-0.001 \\
(0.002)\end{array}$ & $\begin{array}{l}-0.002 \\
(0.002)\end{array}$ & $\begin{array}{c}-0.001 \\
(0.002)\end{array}$ \\
\hline Circulatory & $\begin{array}{c}0.001 \\
(0.003)\end{array}$ & $\begin{array}{l}-0.002 \\
(0.004)\end{array}$ & $\begin{array}{l}-0.001 \\
(0.004)\end{array}$ & $\begin{array}{l}-0.005 \\
(0.004)\end{array}$ & $\begin{array}{l}-0.003 \\
(0.004)\end{array}$ \\
\hline Respiratory & $\begin{array}{c}0.008 * * * \\
(0.002)\end{array}$ & $\begin{array}{c}0.005 * * \\
(0.002)\end{array}$ & $\begin{array}{c}0.005 * * \\
(0.002)\end{array}$ & $\begin{array}{c}0.003 \\
(0.002)\end{array}$ & $\begin{array}{c}0.002 \\
(0.002)\end{array}$ \\
\hline Digestive & $\begin{array}{c}-0.010 * * * \\
(0.003)\end{array}$ & $\begin{array}{l}-0.004 \\
(0.004)\end{array}$ & $\begin{array}{l}-0.005 \\
(0.004)\end{array}$ & $\begin{array}{l}-0.005 \\
(0.004)\end{array}$ & $\begin{array}{l}-0.006 * \\
(0.004)\end{array}$ \\
\hline Genito-urinary & $\begin{array}{l}-0.003 \\
(0.004)\end{array}$ & $\begin{array}{c}0.003 \\
(0.006)\end{array}$ & $\begin{array}{c}0.004 \\
(0.005)\end{array}$ & $\begin{array}{c}0.001 \\
(0.006)\end{array}$ & $\begin{array}{c}0.001 \\
(0.005)\end{array}$ \\
\hline Skin & $\begin{array}{c}0.011 * * * \\
(0.002)\end{array}$ & $\begin{array}{c}0.010 * * * \\
(0.003)\end{array}$ & $\begin{array}{c}0.010 * * * \\
(0.003)\end{array}$ & $\begin{array}{c}0.007 * * \\
(0.003)\end{array}$ & $\begin{array}{c}0.008 * * * \\
(0.003)\end{array}$ \\
\hline Musculoskeletal etc. & $\begin{array}{c}0.002 \\
(0.001)\end{array}$ & $\begin{array}{l}-0.001 \\
(0.002)\end{array}$ & $\begin{array}{l}-0.001 \\
(0.002)\end{array}$ & $\begin{array}{l}-0.002 \\
(0.002)\end{array}$ & $\begin{array}{c}-0.004 * * \\
(0.002)\end{array}$ \\
\hline Congenital anomalies & $\begin{array}{c}-0.026 * * * \\
(0.004)\end{array}$ & $\begin{array}{c}-0.030 * * * \\
(0.005)\end{array}$ & $\begin{array}{c}-0.026 * * * \\
(0.005)\end{array}$ & $\begin{array}{c}-0.017 * * * \\
(0.005)\end{array}$ & $\begin{array}{c}-0.017 * * * \\
(0.005)\end{array}$ \\
\hline Injuries & $\begin{array}{l}-0.004 \\
(0.002)\end{array}$ & $\begin{array}{l}-0.003 \\
(0.003)\end{array}$ & $\begin{array}{l}-0.003 \\
(0.003)\end{array}$ & $\begin{array}{l}-0.004 \\
(0.003)\end{array}$ & $\begin{array}{l}-0.005 \\
(0.003)\end{array}$ \\
\hline Schooling & & & $\begin{array}{c}0.021 * * * \\
(0.001)\end{array}$ & & $\begin{array}{c}0.012 * * * \\
(0.001)\end{array}$ \\
\hline Cognitive ability & & & & $\begin{array}{c}0.016^{* * * *} \\
(0.001)\end{array}$ & $\begin{array}{c}0.011 * * * \\
(0.001)\end{array}$ \\
\hline Non-cognitive ability & & & & $\begin{array}{c}0.017 * * * \\
(0.001)\end{array}$ & $\begin{array}{c}0.014 * * * \\
(0.001)\end{array}$ \\
\hline Sibling fixed effects & No & Yes & Yes & Yes & Yes \\
\hline Occupation fixed effects & $\mathrm{No}$ & No & No & No & Yes \\
\hline Controls for marital status & No & No & No & No & Yes \\
\hline R-squared & 0.027 & 0.014 & 0.115 & 0.033 & 0.161 \\
\hline No. of observations & & & 319,145 & & \\
\hline
\end{tabular}


Table 9. Employment. The penalty for Specific health conditions. Men born 1950-1970.

\begin{tabular}{|c|c|c|c|c|c|}
\hline Variable & (A) & (B) & (C) & (D) & (E) \\
\hline Diabetes & $\begin{array}{c}-0.097 * * * \\
(0.014)\end{array}$ & $\begin{array}{c}-0.103 * * * \\
(0.017)\end{array}$ & $\begin{array}{c}-0.082 * * * \\
(0.016)\end{array}$ & $\begin{array}{c}-0.078 * * \\
(0.038)\end{array}$ & $\begin{array}{c}-0.073 * * \\
(0.037)\end{array}$ \\
\hline Neurosis & $\begin{array}{c}-0.124 * * * \\
(0.004)\end{array}$ & $\begin{array}{c}-0.079 * * * \\
(0.005)\end{array}$ & $\begin{array}{c}-0.075^{* * *} \\
(0.005)\end{array}$ & $\begin{array}{c}-0.050^{* * *} \\
(0.005)\end{array}$ & $\begin{array}{c}-0.049 * * * \\
(0.005)\end{array}$ \\
\hline Personality disorder & $\begin{array}{c}-0.164 * * * \\
(0.008)\end{array}$ & $\begin{array}{c}-0.110 * * * \\
(0.009)\end{array}$ & $\begin{array}{c}-0.105^{* * *} \\
(0.009)\end{array}$ & $\begin{array}{c}-0.080 * * * \\
(0.009)\end{array}$ & $\begin{array}{c}-0.075 * * * \\
(0.009)\end{array}$ \\
\hline Alcoholism and drug dependence & $\begin{array}{c}-0.274 * * * \\
(0.010)\end{array}$ & $\begin{array}{c}-0.191 * * * \\
(0.012)\end{array}$ & $\begin{array}{c}-0.179 * * * \\
(0.012)\end{array}$ & $\begin{array}{c}-0.146^{* * *} \\
(0.013)\end{array}$ & $\begin{array}{c}-0.138 * * * \\
(0.013)\end{array}$ \\
\hline Epilepsy & $\begin{array}{c}-0.078 * * * \\
(0.010)\end{array}$ & $\begin{array}{c}-0.078 * * * \\
(0.012)\end{array}$ & $\begin{array}{c}-0.073 * * * \\
(0.012)\end{array}$ & $\begin{array}{c}-0.036^{* * * *} \\
(0.012)\end{array}$ & $\begin{array}{c}-0.033 * * * \\
(0.012)\end{array}$ \\
\hline Migraine & $\begin{array}{l}-0.002 \\
(0.005)\end{array}$ & $\begin{array}{l}-0.007 \\
(0.007)\end{array}$ & $\begin{array}{l}-0.008 \\
(0.007)\end{array}$ & $\begin{array}{l}-0.007 \\
(0.007)\end{array}$ & $\begin{array}{c}-0.009 \\
(0.007)\end{array}$ \\
\hline Asthma & $\begin{array}{l}-0.004 \\
(0.003)\end{array}$ & $\begin{array}{l}-0.002 \\
(0.004)\end{array}$ & $\begin{array}{l}-0.001 \\
(0.004)\end{array}$ & $\begin{array}{l}-0.001 \\
(0.004)\end{array}$ & $\begin{array}{l}-0.002 \\
(0.004)\end{array}$ \\
\hline Hay fever & $\begin{array}{c}0.014 * * * \\
(0.002)\end{array}$ & $\begin{array}{c}0.007 * * * \\
(0.003)\end{array}$ & $\begin{array}{c}0.006 * * \\
(0.002)\end{array}$ & $\begin{array}{c}0.004 \\
(0.003)\end{array}$ & $\begin{array}{c}0.004 \\
(0.002)\end{array}$ \\
\hline Vertebrogenic pain syndrome & $\begin{array}{c}-0.007 * * * \\
(0.002)\end{array}$ & $\begin{array}{c}-0.007 * * \\
(0.003)\end{array}$ & $\begin{array}{c}-0.007 * * \\
(0.003)\end{array}$ & $\begin{array}{c}-0.006 * * \\
(0.003)\end{array}$ & $\begin{array}{c}-0.008 * * * \\
(0.003)\end{array}$ \\
\hline Schooling & & & $\begin{array}{c}0.021 * * * \\
(0.001)\end{array}$ & & $\begin{array}{c}0.012 * * * \\
(0.001)\end{array}$ \\
\hline Cognitive ability & & & & $\begin{array}{c}0.016^{* * *} \\
(0.001)\end{array}$ & $\begin{array}{c}0.011^{* * *} \\
(0.001)\end{array}$ \\
\hline Non-cognitive ability & & & & $\begin{array}{c}0.018 * * * \\
(0.001)\end{array}$ & $\begin{array}{c}0.014 * * * \\
(0.001)\end{array}$ \\
\hline Sibling fixed effects & No & Yes & Yes & Yes & Yes \\
\hline Occupation fixed effects & No & No & No & No & Yes \\
\hline Controls for marital status & No & No & No & No & Yes \\
\hline R-squared & 0.023 & 0.011 & 0.113 & 0.029 & 0.159 \\
\hline No. of observations & & & 319,145 & & \\
\hline
\end{tabular}


Table A1: Descriptive statistics for the sample including individuals with zero earnings.

\begin{tabular}{|c|c|c|}
\hline Non-binary variables & Mean (std) & Missing observations \\
\hline (Log) earnings & $12.383(0.825)$ & - \\
\hline Global health & $2.250(3.935)$ & - \\
\hline Years of schooling & $11.750(2.222)$ & 3,499 \\
\hline Cognitive ability & $5.067(1.956)$ & 4,958 \\
\hline Non-cognitive ability & $5.056(1.756)$ & 9,268 \\
\hline Binary variables & Mean & Prevalence \\
\hline Positive earnings & 0.917 & 26,494 \\
\hline Any diagnose & 0.503 & 160,510 \\
\hline Tumors & 0.002 & 509 \\
\hline Endocrine etc. & 0.015 & 4,692 \\
\hline Mental & 0.078 & 24,999 \\
\hline Nervous & 0.015 & 4,761 \\
\hline Sensory & 0.158 & 50,301 \\
\hline Circulatory & 0.026 & 8,377 \\
\hline Respiratory & 0.107 & 34,087 \\
\hline Digestive & 0.032 & 10,109 \\
\hline Genito-urinary & 0.013 & 4,258 \\
\hline Skin & 0.052 & 16,554 \\
\hline Musculoskeletal etc. & 0.136 & 43,489 \\
\hline Congenital anomalies & 0.017 & 5,267 \\
\hline Injuries & 0.048 & 15,160 \\
\hline Diabetes & 0.002 & 664 \\
\hline Neurosis & 0.033 & 10,440 \\
\hline Personality disorder & 0.011 & 3,402 \\
\hline Alcoholism and drug dependence & 0.008 & 2,417 \\
\hline Epilepsy & 0.004 & 1,253 \\
\hline Migraine & 0.009 & 2,800 \\
\hline Asthma & 0.025 & 7,826 \\
\hline Hay fever & 0.064 & 20,512 \\
\hline Vertebrogenic pain syndrome & 0.057 & 18,262 \\
\hline
\end{tabular}

Notes: The table shows descriptive statistics before the standardization of control variables and refers to the sample including individuals with zero earnings. 
Table A2: Descriptive statistics for the sample not restricted to individuals with at least one brother.

\begin{tabular}{|c|c|c|}
\hline Non-binary variables & Mean (std) & Missing observations \\
\hline (Log) earnings & $12.39(0.83)$ & - \\
\hline Global health & $2.07(3.71)$ & - \\
\hline Years of schooling & $11.95(2.24)$ & 589 \\
\hline Cognitive ability & $0.00(1.00)$ & 8,315 \\
\hline Non-cognitive ability & $0.00(1.00)$ & 17,720 \\
\hline Binary variables & Mean & Incidence \\
\hline Any diagnose & 0.507 & 359,691 \\
\hline Tumor & 0.002 & 1,126 \\
\hline Endocrine etc. & 0.016 & 11,038 \\
\hline Mental & 0.064 & 45,305 \\
\hline Nervous system & 0.015 & 10,578 \\
\hline Sensory organs & 0.152 & 107,767 \\
\hline Circulatory & 0.027 & 19,367 \\
\hline Respiratory & 0.121 & 86,074 \\
\hline Digestive & 0.030 & 21,493 \\
\hline Genito-urinary & 0.014 & 10,032 \\
\hline Skin & 0.054 & 38,317 \\
\hline Musculoskeletal etc. & 0.136 & 96,530 \\
\hline Congenital anomalies & 0.017 & 11,988 \\
\hline Injuries and poisonings & 0.049 & 34,612 \\
\hline Diabetes & 0.002 & 1,479 \\
\hline Neurosis & 0.028 & 19,972 \\
\hline Personality disorder & 0.008 & 5,712 \\
\hline Alcoholism and drug dependence & 0.005 & 3,273 \\
\hline Epilepsy & 0.004 & 2,497 \\
\hline Migraine & 0.009 & 6,605 \\
\hline Asthma & 0.027 & 19,404 \\
\hline Hay fever & 0.076 & 54,084 \\
\hline Vertebrogenic pain syndrome & 0.054 & 38,240 \\
\hline Number of observations & 710,018 & \\
\hline
\end{tabular}

Note: The table shows descriptive statistics before the standardization of control variables. 
Table A3. Restricting the sample to individuals with at least SEK 100,000 in annual earnings in 2003. The earnings penalty for Global health. Men born 1950-1970. Logarithm of earnings.

\begin{tabular}{lccccc}
\hline Variable & $(\mathrm{A})$ & $(\mathrm{B})$ & $(\mathrm{C})$ & $(\mathrm{D})$ & $(\mathrm{E})$ \\
\hline Global health(*10) & & & & & \\
& $-0.125^{* * *}$ & $-0.076^{* * *}$ & $-0.061^{* * *}$ & $-0.014^{* * *}$ & $-0.015^{* * *}$ \\
Schooling: & $(0.002)$ & $(0.003)$ & $(0.003)$ & $(0.003)$ & $(0.003)$ \\
& & & $0.122^{* * *}$ & & $0.060^{* * *}$ \\
Cognitive ability: & & & $(0.001)$ & & $(0.002)$ \\
& & & & $0.088^{* * *}$ & $0.028^{* * *}$ \\
Non-cognitive ability: & & & $(0.001)$ & $(0.001)$ \\
& & & & $0.051^{* * *}$ & $0.029^{* * *}$ \\
& & & & & \\
Sibling fixed effects & No & Yes & Yes & Yes & Yes \\
\hline Occupation fixed effects & No & No & No & No & Yes \\
\hline Controls for marital status & No & No & No & No & Yes \\
\hline R2 & 0.018 & 0.017 & 0.084 & 0.069 & 0.292 \\
\hline No. of observations & & & 238,625 & & \\
\hline
\end{tabular}

Notes: All regressions were run using robust standard errors. Fixed effects for birth cohort were included. * indicates significance at the 10 percent level, ** indicates significance at the 5 percent level, and $* * *$ indicates significance at the 1 percent level. In sibling fixed effects models, R2 refers to the within-siblings R2. 
Table A4: Restricting the sample to individuals with at least SEK 100,000 in annual earnings in 2003. The earnings penalty for Global health. Men born 1950-1970. Logarithm of earnings.

Twins.

\begin{tabular}{|c|c|c|c|c|c|c|}
\hline Variable & $(\mathrm{A})$ & (B) & $(\mathrm{C})$ & (D) & $(\mathrm{E})$ & $(\mathrm{F})$ \\
\hline Global health $(* 10)$ & $\begin{array}{c}-0.131 * * * \\
(0.014)\end{array}$ & $\begin{array}{c}-0.067 * * * \\
(0.020)\end{array}$ & $\begin{array}{c}-0.141 * * * \\
(0.024)\end{array}$ & $\begin{array}{c}-0.100 * * * \\
(0.032)\end{array}$ & $\begin{array}{c}-0.108 * * * \\
(0.028)\end{array}$ & $\begin{array}{l}-0.042 \\
(0.037)\end{array}$ \\
\hline Type of twin & All & All & $\mathrm{DZ}$ & $\mathrm{DZ}$ & $\mathrm{MZ}$ & $\mathrm{MZ}$ \\
\hline Twin fixed effects & No & Yes & No & Yes & No & Yes \\
\hline $\mathrm{R} 2$ & 0.014 & 0.004 & 0.015 & 0.008 & 0.008 & 0.002 \\
\hline No. of observations & 5,662 & 5,662 & 2,316 & 2,316 & 1,746 & 1,746 \\
\hline
\end{tabular}


Table A5: Restricting the sample to individuals with at least SEK 100,000 in annual earnings in 2003. The earnings penalty for Broad categories of health conditions. Men born 1950-1970.

Logarithm of earnings.

\begin{tabular}{|c|c|c|c|c|c|}
\hline Variable & $(\mathrm{A})$ & (B) & $(\mathrm{C})$ & (D) & $(\mathrm{E})$ \\
\hline Diagnose $=1$ : & $\begin{array}{c}-0.060 * * * \\
(0.002)\end{array}$ & $\begin{array}{c}-0.032 * * * \\
(0.002)\end{array}$ & $\begin{array}{c}-0.024 * * * \\
(0.002)\end{array}$ & $\begin{array}{c}-0.007 * * * \\
(0.002)\end{array}$ & $\begin{array}{c}-0.005^{* *} \\
(0.002)\end{array}$ \\
\hline \multicolumn{6}{|l|}{ By type: } \\
\hline Tumors & $\begin{array}{l}-0.011 \\
(0.021)\end{array}$ & $\begin{array}{l}-0.037 \\
(0.025)\end{array}$ & $\begin{array}{l}-0.030 \\
(0.025)\end{array}$ & $\begin{array}{l}-0.010 \\
(0.026)\end{array}$ & $\begin{array}{c}0.006 \\
(0.021)\end{array}$ \\
\hline Endocrine etc. & $\begin{array}{c}-0.093 * * * \\
(0.006)\end{array}$ & $\begin{array}{c}-0.049 * * * \\
(0.008)\end{array}$ & $\begin{array}{c}-0.036^{* * *} \\
(0.008)\end{array}$ & $\begin{array}{c}-0.017^{* *} \\
(0.009)\end{array}$ & $\begin{array}{l}-0.004 \\
(0.008)\end{array}$ \\
\hline Mental & $\begin{array}{c}-0.157 * * * \\
(0.003)\end{array}$ & $\begin{array}{c}-0.090 * * * \\
(0.004)\end{array}$ & $\begin{array}{c}-0.069^{* * *} \\
(0.004)\end{array}$ & $\begin{array}{l}-0.001 \\
(0.005)\end{array}$ & $\begin{array}{l}-0.008^{*} \\
(0.004)\end{array}$ \\
\hline Nervous system & $\begin{array}{c}-0.063 * * * \\
(0.007)\end{array}$ & $\begin{array}{c}-0.059 * * * \\
(0.009)\end{array}$ & $\begin{array}{c}-0.050^{* * *} \\
(0.009)\end{array}$ & $\begin{array}{c}-0.024 * * * \\
(0.009)\end{array}$ & $\begin{array}{c}-0.023 * * * \\
(0.008)\end{array}$ \\
\hline Sensory organs & $\begin{array}{c}-0.038 * * * \\
(0.002)\end{array}$ & $\begin{array}{c}-0.018 * * * \\
(0.003)\end{array}$ & $\begin{array}{c}-0.015^{* * *} \\
(0.003)\end{array}$ & $\begin{array}{c}-0.009 * * * \\
(0.003)\end{array}$ & $\begin{array}{c}-0.006^{* *} \\
(0.002)\end{array}$ \\
\hline Circulatory & $\begin{array}{c}0.006 \\
(0.005)\end{array}$ & $\begin{array}{c}0.014 * * \\
(0.006)\end{array}$ & $\begin{array}{c}0.013 * * \\
(0.006)\end{array}$ & $\begin{array}{l}0.011^{*} \\
(0.006)\end{array}$ & $\begin{array}{l}0.009^{*} \\
(0.005)\end{array}$ \\
\hline Respiratory & $\begin{array}{c}0.017 * * * \\
(0.003)\end{array}$ & $\begin{array}{l}-0.003 \\
(0.003)\end{array}$ & $\begin{array}{l}-0.004 \\
(0.003)\end{array}$ & $\begin{array}{l}-0.000 \\
(0.003)\end{array}$ & $\begin{array}{l}-0.003 \\
(0.003)\end{array}$ \\
\hline Digestive & $\begin{array}{c}-0.032 * * * \\
(0.005)\end{array}$ & $\begin{array}{c}-0.013 * * \\
(0.006)\end{array}$ & $\begin{array}{c}-0.009 \\
(0.006)\end{array}$ & $\begin{array}{l}-0.004 \\
(0.006)\end{array}$ & $\begin{array}{l}-0.001 \\
(0.005)\end{array}$ \\
\hline Genito-urinary & $\begin{array}{c}-0.014^{*} \\
(0.007)\end{array}$ & $\begin{array}{l}-0.013 \\
(0.009)\end{array}$ & $\begin{array}{l}-0.011 \\
(0.009)\end{array}$ & $\begin{array}{l}-0.009 \\
(0.009)\end{array}$ & $\begin{array}{l}-0.010 \\
(0.008)\end{array}$ \\
\hline Skin & $\begin{array}{l}-0.001 \\
(0.004)\end{array}$ & $\begin{array}{l}-0.002 \\
(0.005)\end{array}$ & $\begin{array}{l}-0.000 \\
(0.004)\end{array}$ & $\begin{array}{c}0.001 \\
(0.005)\end{array}$ & $\begin{array}{c}0.006 \\
(0.004)\end{array}$ \\
\hline Musculoskeletal etc. & $\begin{array}{c}-0.044 * * * \\
(0.002)\end{array}$ & $\begin{array}{c}-0.019 * * * \\
(0.003)\end{array}$ & $\begin{array}{c}-0.012 * * * \\
(0.003)\end{array}$ & $\begin{array}{c}-0.008 * * * \\
(0.003)\end{array}$ & $\begin{array}{c}-0.006^{* *} \\
(0.003)\end{array}$ \\
\hline Congenital anomalies & $\begin{array}{c}-0.033 * * * \\
(0.006)\end{array}$ & $\begin{array}{c}-0.023 * * * \\
(0.008)\end{array}$ & $\begin{array}{c}-0.022 * * * \\
(0.008)\end{array}$ & $\begin{array}{l}-0.007 \\
(0.008)\end{array}$ & $\begin{array}{c}-0.013 * \\
(0.007)\end{array}$ \\
\hline Injuries & $\begin{array}{c}-0.019 * * * \\
(0.004)\end{array}$ & $\begin{array}{l}-0.008^{*} \\
(0.005)\end{array}$ & $\begin{array}{c}-0.002 \\
(0.005)\end{array}$ & $\begin{array}{c}-0.002 \\
(0.005)\end{array}$ & $\begin{array}{c}0.001 \\
(0.004)\end{array}$ \\
\hline Schooling & & & $\begin{array}{c}0.122 * * * \\
(0.001)\end{array}$ & & $\begin{array}{c}0.060 * * * \\
(0.002)\end{array}$ \\
\hline Cognitive ability & & & & $\begin{array}{c}0.088^{* * *} * \\
(0.001)\end{array}$ & $\begin{array}{c}0.028 * * * \\
(0.001)\end{array}$ \\
\hline Non-cognitive ability & & & & $\begin{array}{c}0.051 * * * \\
(0.001)\end{array}$ & $\begin{array}{c}0.029^{* * *} \\
(0.001)\end{array}$ \\
\hline Sibling fixed effects & No & Yes & Yes & Yes & Yes \\
\hline Occupation fixed effects & No & No & No & No & Yes \\
\hline Controls for marital status & No & No & No & No & Yes \\
\hline R-squared & 0.021 & 0.017 & 0.084 & 0.070 & 0.292 \\
\hline No. of observations & & & 238,625 & & \\
\hline
\end{tabular}


Table A6: Restricting the sample to individuals with at least SEK 100,000 in annual earnings in 2003. The earnings penalty for Specific health conditions. Men born 1950-1970. Logarithm of earnings.

\begin{tabular}{|c|c|c|c|c|c|}
\hline Variable & $(\mathrm{A})$ & (B) & $(\mathrm{C})$ & (D) & (E) \\
\hline Diabetes & $\begin{array}{c}-0.085 * * * \\
(0.019)\end{array}$ & $\begin{array}{c}-0.099 * * * \\
(0.024)\end{array}$ & $\begin{array}{c}-0.089 * * * \\
(0.022)\end{array}$ & $\begin{array}{l}-0.041 \\
(0.053)\end{array}$ & $\begin{array}{l}-0.039 \\
(0.050)\end{array}$ \\
\hline Neurosis & $\begin{array}{c}-0.142 * * * \\
(0.005)\end{array}$ & $\begin{array}{c}-0.089 * * * \\
(0.007)\end{array}$ & $\begin{array}{c}-0.071 * * * \\
(0.007)\end{array}$ & $\begin{array}{l}-0.005 \\
(0.007)\end{array}$ & $\begin{array}{c}-0.012 * \\
(0.006)\end{array}$ \\
\hline Personality disorder & $\begin{array}{c}-0.189 * * * \\
(0.009)\end{array}$ & $\begin{array}{c}-0.106^{* * *} \\
(0.011)\end{array}$ & $\begin{array}{c}-0.083 * * * \\
(0.011)\end{array}$ & $\begin{array}{l}-0.016 \\
(0.011)\end{array}$ & $\begin{array}{l}-0.015 \\
(0.010)\end{array}$ \\
\hline Alcoholism and drug dependence & $\begin{array}{c}-0.201 * * * \\
(0.012)\end{array}$ & $\begin{array}{c}-0.111 * * * \\
(0.016)\end{array}$ & $\begin{array}{c}-0.085 * * * \\
(0.016)\end{array}$ & $\begin{array}{l}-0.019 \\
(0.017)\end{array}$ & $\begin{array}{l}-0.003 \\
(0.015)\end{array}$ \\
\hline Epilepsy & $\begin{array}{c}-0.099 * * * \\
(0.013)\end{array}$ & $\begin{array}{c}-0.092 * * * \\
(0.017)\end{array}$ & $\begin{array}{c}-0.080 * * * \\
(0.016)\end{array}$ & $\begin{array}{l}-0.023 \\
(0.018)\end{array}$ & $\begin{array}{c}-0.030 * * \\
(0.015)\end{array}$ \\
\hline Migraine & $\begin{array}{c}-0.041 * * * \\
(0.009)\end{array}$ & $\begin{array}{c}-0.029 * * \\
(0.011)\end{array}$ & $\begin{array}{c}-0.022 * * \\
(0.011)\end{array}$ & $\begin{array}{l}-0.018 \\
(0.011)\end{array}$ & $\begin{array}{l}-0.018 * \\
(0.010)\end{array}$ \\
\hline Asthma & $\begin{array}{c}-0.020 * * * \\
(0.005)\end{array}$ & $\begin{array}{l}-0.011 * \\
(0.007)\end{array}$ & $\begin{array}{l}-0.011 * \\
(0.006)\end{array}$ & $\begin{array}{l}-0.003 \\
(0.007)\end{array}$ & $\begin{array}{c}-0.013 * * \\
(0.006)\end{array}$ \\
\hline Hay fever & $\begin{array}{c}0.042 * * * \\
(0.003)\end{array}$ & $\begin{array}{c}0.002 \\
(0.004)\end{array}$ & $\begin{array}{l}-0.000 \\
(0.004)\end{array}$ & $\begin{array}{c}0.001 \\
(0.004)\end{array}$ & $\begin{array}{c}0.001 \\
(0.004)\end{array}$ \\
\hline Vertebrogenic pain syndrome & $\begin{array}{c}-0.064 * * * \\
(0.004)\end{array}$ & $\begin{array}{c}-0.017 * * * \\
(0.004)\end{array}$ & $\begin{array}{l}-0.007 \\
(0.004)\end{array}$ & $\begin{array}{l}-0.000 \\
(0.004)\end{array}$ & $\begin{array}{c}0.001 \\
(0.004)\end{array}$ \\
\hline Schooling & & & $\begin{array}{c}0.123 * * * \\
(0.001)\end{array}$ & & $\begin{array}{c}0.060 * * * \\
(0.002)\end{array}$ \\
\hline Cognitive ability & & & & $\begin{array}{c}0.088 * * * \\
(0.001)\end{array}$ & $\begin{array}{c}0.028 * * * \\
(0.001)\end{array}$ \\
\hline Non-cognitive ability & & & & $\begin{array}{c}0.051 * * * \\
(0.001)\end{array}$ & $\begin{array}{c}0.029 * * * \\
(0.001)\end{array}$ \\
\hline Sibling fixed effects & No & Yes & Yes & Yes & Yes \\
\hline Occupation fixed effects & No & No & No & No & Yes \\
\hline Controls for marital status & No & No & No & No & Yes \\
\hline R-squared & 0.019 & 0.016 & 0.083 & 0.069 & 0.292 \\
\hline No. of observations & & & 238,625 & & \\
\hline
\end{tabular}


Table A7. Benefits as a share of income in 2003. The penalty for Global health. Men born 19501970.

\begin{tabular}{|c|c|c|c|c|c|}
\hline Variable & $(\mathrm{A})$ & (B) & (C) & (D) & $(\mathrm{E})$ \\
\hline Global health $(* 10)$ & $\begin{array}{c}0.038 * * * \\
(0.001)\end{array}$ & $\begin{array}{c}0.027 * * * \\
(0.001)\end{array}$ & $\begin{array}{c}0.026 * * * \\
(0.001)\end{array}$ & $\begin{array}{c}0.018 * * * \\
(0.002)\end{array}$ & $\begin{array}{c}0.018 * * * \\
(0.002)\end{array}$ \\
\hline Schooling: & & & $\begin{array}{c}-0.008 * * * \\
(0.001)\end{array}$ & & $\begin{array}{c}-0.005 * * * \\
(0.001)\end{array}$ \\
\hline Cognitive ability: & & & & $\begin{array}{c}-0.009 * * * \\
(0.001)\end{array}$ & $\begin{array}{c}-0.007 * * * \\
(0.001)\end{array}$ \\
\hline Non-cognitive ability: & & & & $\begin{array}{c}-0.006^{* * *} * \\
(0.001)\end{array}$ & $\begin{array}{c}-0.006 * * * \\
(0.001)\end{array}$ \\
\hline Sibling fixed effects & No & Yes & Yes & Yes & Yes \\
\hline Occupation fixed effects & No & No & No & No & Yes \\
\hline Controls for marital status & No & No & No & No & Yes \\
\hline R2 & 0.007 & 0.004 & 0.005 & 0.007 & 0.008 \\
\hline No. of observations & & & 283,495 & & \\
\hline
\end{tabular}

Notes: All regressions were run using robust standard errors. Fixed effects for birth cohort were included. * indicates significance at the 10 percent level, ** indicates significance at the 5 percent level, and *** indicates significance at the 1 percent level. In sibling fixed effects models, R2 refers to the within-siblings R2. 
Table A8: Benefits as a share of income in 2003. The penalty for Global health. Men born 19501970. Twins.

\begin{tabular}{|c|c|c|c|c|c|c|}
\hline Variable & (A) & (B) & (C) & (D) & (E) & $(\mathrm{F})$ \\
\hline Global health $(* 10)$ & $\begin{array}{c}0.041 * * * \\
(0.005)\end{array}$ & $\begin{array}{c}0.026^{* * * *} \\
(0.008)\end{array}$ & $\begin{array}{c}0.037 * * * \\
(0.008)\end{array}$ & $\begin{array}{c}0.017 \\
(0.012)\end{array}$ & $\begin{array}{c}0.035^{* * *} * \\
(0.008)\end{array}$ & $\begin{array}{c}0.053 * * * \\
(0.014)\end{array}$ \\
\hline Type of twin & All & All & DZ & $\mathrm{DZ}$ & $\mathrm{MZ}$ & $\mathrm{MZ}$ \\
\hline Twin fixed effects & No & Yes & No & Yes & No & Yes \\
\hline R2 & 0.009 & 0.003 & 0.007 & 0.001 & 0.008 & 0.012 \\
\hline No. of observations & 6,636 & 6,636 & 3,110 & 3,110 & 2,272 & 2,272 \\
\hline
\end{tabular}


Table A9: Benefits as a share of income in 2003. The penalty for Broad categories of health conditions. Men born 1950-1970.

\begin{tabular}{|c|c|c|c|c|c|}
\hline Variable & (A) & (B) & (C) & (D) & (E) \\
\hline Diagnose $=1$ : & $\begin{array}{c}0.017 * * * \\
(0.001)\end{array}$ & $\begin{array}{c}0.011 * * * \\
(0.001)\end{array}$ & $\begin{array}{c}0.010 * * * \\
(0.001)\end{array}$ & $\begin{array}{c}0.007 * * * \\
(0.001)\end{array}$ & $\begin{array}{c}0.007 * * * \\
(0.001)\end{array}$ \\
\hline \multicolumn{6}{|l|}{ By type: } \\
\hline Tumors & $\begin{array}{c}0.004 \\
(0.009)\end{array}$ & $\begin{array}{c}-0.006 \\
(0.014)\end{array}$ & $\begin{array}{c}-0.007 \\
(0.014)\end{array}$ & $\begin{array}{c}-0.008 \\
(0.014)\end{array}$ & $\begin{array}{c}-0.008 \\
(0.014)\end{array}$ \\
\hline Endocrine etc. & $\begin{array}{c}0.026 * * * \\
(0.004)\end{array}$ & $\begin{array}{c}0.014 * * * \\
(0.005)\end{array}$ & $\begin{array}{c}0.014 * * * \\
(0.005)\end{array}$ & $\begin{array}{c}0.007 \\
(0.005)\end{array}$ & $\begin{array}{c}0.007 \\
(0.005)\end{array}$ \\
\hline Mental & $\begin{array}{c}0.046 * * * \\
(0.002)\end{array}$ & $\begin{array}{c}0.034 * * * \\
(0.002)\end{array}$ & $\begin{array}{c}0.033 * * * \\
(0.002)\end{array}$ & $\begin{array}{c}0.022 * * * \\
(0.002)\end{array}$ & $\begin{array}{c}0.022 * * * \\
(0.002)\end{array}$ \\
\hline Nervous system & $\begin{array}{c}0.018 * * * \\
(0.003)\end{array}$ & $\begin{array}{c}0.012 * * * \\
(0.004)\end{array}$ & $\begin{array}{c}0.011 * * * \\
(0.004)\end{array}$ & $\begin{array}{c}0.007 \\
(0.004)\end{array}$ & $\begin{array}{c}0.007 \\
(0.004)\end{array}$ \\
\hline Sensory organs & $\begin{array}{c}0.004 * * * \\
(0.001)\end{array}$ & $\begin{array}{c}0.002 \\
(0.001)\end{array}$ & $\begin{array}{c}0.002 \\
(0.001)\end{array}$ & $\begin{array}{c}0.001 \\
(0.001)\end{array}$ & $\begin{array}{c}0.001 \\
(0.001)\end{array}$ \\
\hline Circulatory & $\begin{array}{c}0.001 \\
(0.002)\end{array}$ & $\begin{array}{l}-0.001 \\
(0.003)\end{array}$ & $\begin{array}{l}-0.001 \\
(0.003)\end{array}$ & $\begin{array}{c}0.000 \\
(0.003)\end{array}$ & $\begin{array}{l}-0.000 \\
(0.003)\end{array}$ \\
\hline Respiratory & $\begin{array}{c}0.001 \\
(0.001)\end{array}$ & $\begin{array}{l}0.003 * \\
(0.001)\end{array}$ & $\begin{array}{l}0.003 * \\
(0.001)\end{array}$ & $\begin{array}{l}0.003 * \\
(0.001)\end{array}$ & $\begin{array}{l}0.003 * \\
(0.001)\end{array}$ \\
\hline Digestive & $\begin{array}{c}0.015 * * * \\
(0.002)\end{array}$ & $\begin{array}{c}0.012 * * * \\
(0.003)\end{array}$ & $\begin{array}{c}0.011 * * * \\
(0.003)\end{array}$ & $\begin{array}{c}0.011 * * * \\
(0.003)\end{array}$ & $\begin{array}{c}0.011 * * * \\
(0.003)\end{array}$ \\
\hline Genito-urinary & $\begin{array}{c}0.003 \\
(0.003)\end{array}$ & $\begin{array}{c}0.002 \\
(0.004)\end{array}$ & $\begin{array}{c}0.002 \\
(0.004)\end{array}$ & $\begin{array}{c}0.001 \\
(0.004)\end{array}$ & $\begin{array}{c}0.001 \\
(0.004)\end{array}$ \\
\hline Skin & $\begin{array}{c}-0.001 \\
(0.001)\end{array}$ & $\begin{array}{l}-0.003 \\
(0.002)\end{array}$ & $\begin{array}{l}-0.003 \\
(0.002)\end{array}$ & $\begin{array}{l}-0.003 \\
(0.002)\end{array}$ & $\begin{array}{l}-0.003 \\
(0.002)\end{array}$ \\
\hline Musculoskeletal etc. & $\begin{array}{c}0.012 * * * \\
(0.001)\end{array}$ & $\begin{array}{c}0.006 * * * \\
(0.001)\end{array}$ & $\begin{array}{c}0.006 * * * \\
(0.001)\end{array}$ & $\begin{array}{c}0.006^{* * *} \\
(0.001)\end{array}$ & $\begin{array}{c}0.006^{* * *} * \\
(0.001)\end{array}$ \\
\hline Congenital anomalies & $\begin{array}{c}0.002 \\
(0.003)\end{array}$ & $\begin{array}{l}0.007 * \\
(0.003)\end{array}$ & $\begin{array}{c}0.006 * \\
(0.003)\end{array}$ & $\begin{array}{c}0.004 \\
(0.004)\end{array}$ & $\begin{array}{c}0.004 \\
(0.004)\end{array}$ \\
\hline Injuries & $\begin{array}{c}0.009 * * * \\
(0.002)\end{array}$ & $\begin{array}{c}0.008 * * * \\
(0.002)\end{array}$ & $\begin{array}{c}0.007 * * * \\
(0.002)\end{array}$ & $\begin{array}{c}0.007 * * * \\
(0.002)\end{array}$ & $\begin{array}{c}0.007 * * * \\
(0.002)\end{array}$ \\
\hline Schooling & & & $\begin{array}{c}-0.008 * * * \\
(0.001)\end{array}$ & & $\begin{array}{c}-0.005 * * * \\
(0.001)\end{array}$ \\
\hline Cognitive ability & & & & $\begin{array}{c}-0.009 * * * \\
(0.001)\end{array}$ & $\begin{array}{c}-0.007 * * * \\
(0.001)\end{array}$ \\
\hline Non-cognitive ability & & & & $\begin{array}{c}-0.006 * * * \\
(0.001)\end{array}$ & $\begin{array}{c}-0.005 * * * \\
(0.001)\end{array}$ \\
\hline Sibling fixed effects & No & Yes & Yes & Yes & Yes \\
\hline Occupation fixed effects & No & No & No & No & Yes \\
\hline Controls for marital status & No & No & No & No & Yes \\
\hline R-squared & 0.008 & 0.004 & 0.005 & 0.007 & 0.009 \\
\hline No. of observations & & & 283,495 & & \\
\hline $\begin{array}{l}\text { Notes: The parameter es } \\
\text { regressions were run us } \\
\text { significance at the } 10 \text { per }\end{array}$ & D & . & $\begin{array}{l}\text { at level } \\
\text { blings }\end{array}$ & * indica & $\begin{array}{l}\text { by type. } \\
* \text { indica } \\
\text { gnificance }\end{array}$ \\
\hline
\end{tabular}


Table A10: Benefits as a share of income in 2003. The penalty for Specific health conditions.

Men born 1950-1970.

\begin{tabular}{|c|c|c|c|c|c|}
\hline Variable & (A) & (B) & (C) & (D) & $(\mathrm{E})$ \\
\hline Diabetes & $\begin{array}{c}0.055^{* * *} * \\
(0.010)\end{array}$ & $\begin{array}{c}0.052 * * * \\
(0.013)\end{array}$ & $\begin{array}{c}0.051 * * * \\
(0.013)\end{array}$ & $\begin{array}{c}0.020 \\
(0.029)\end{array}$ & $\begin{array}{c}0.019 \\
(0.029)\end{array}$ \\
\hline Neurosis & $\begin{array}{c}0.047 * * * \\
(0.003)\end{array}$ & $\begin{array}{c}0.035 * * * \\
(0.004)\end{array}$ & $\begin{array}{c}0.034 * * * \\
(0.004)\end{array}$ & $\begin{array}{c}0.024 * * * \\
(0.004)\end{array}$ & $\begin{array}{c}0.024 * * * \\
(0.004)\end{array}$ \\
\hline Personality disorder & $\begin{array}{c}0.050 * * * \\
(0.005)\end{array}$ & $\begin{array}{c}0.036 * * * \\
(0.006)\end{array}$ & $\begin{array}{c}0.035 * * * \\
(0.006)\end{array}$ & $\begin{array}{c}0.023 * * * \\
(0.006)\end{array}$ & $\begin{array}{c}0.023 * * * \\
(0.006)\end{array}$ \\
\hline Alcoholism and drug dependence & $\begin{array}{c}0.090 * * * \\
(0.008)\end{array}$ & $\begin{array}{c}0.073 * * * \\
(0.010)\end{array}$ & $\begin{array}{c}0.071 * * * \\
(0.010)\end{array}$ & $\begin{array}{c}0.054 * * * \\
(0.011)\end{array}$ & $\begin{array}{c}0.053 * * * \\
(0.011)\end{array}$ \\
\hline Epilepsy & $\begin{array}{c}0.033 * * * \\
(0.007)\end{array}$ & $\begin{array}{c}0.027 * * * \\
(0.009)\end{array}$ & $\begin{array}{c}0.027 * * * \\
(0.009)\end{array}$ & $\begin{array}{c}0.015 \\
(0.010)\end{array}$ & $\begin{array}{c}0.016 \\
(0.010)\end{array}$ \\
\hline Migraine & $\begin{array}{c}0.012 * * * \\
(0.004)\end{array}$ & $\begin{array}{c}0.005 \\
(0.005)\end{array}$ & $\begin{array}{c}0.004 \\
(0.005)\end{array}$ & $\begin{array}{c}0.005 \\
(0.005)\end{array}$ & $\begin{array}{c}0.005 \\
(0.005)\end{array}$ \\
\hline Asthma & $\begin{array}{c}0.008 * * * \\
(0.002)\end{array}$ & $\begin{array}{c}0.003 \\
(0.003)\end{array}$ & $\begin{array}{c}0.003 \\
(0.003)\end{array}$ & $\begin{array}{c}0.002 \\
(0.003)\end{array}$ & $\begin{array}{c}0.002 \\
(0.003)\end{array}$ \\
\hline Hay fever & $\begin{array}{c}-0.003 * * \\
(0.001)\end{array}$ & $\begin{array}{c}0.002 \\
(0.002)\end{array}$ & $\begin{array}{c}0.002 \\
(0.002)\end{array}$ & $\begin{array}{c}0.002 \\
(0.002)\end{array}$ & $\begin{array}{c}0.002 \\
(0.002)\end{array}$ \\
\hline Vertebrogenic pain syndrome & $\begin{array}{c}0.017 * * * \\
(0.002)\end{array}$ & $\begin{array}{c}0.006^{* * *} \\
(0.002)\end{array}$ & $\begin{array}{c}0.006^{* * *} \\
(0.002)\end{array}$ & $\begin{array}{c}0.005 * * \\
(0.002)\end{array}$ & $\begin{array}{c}0.005 * * \\
(0.002)\end{array}$ \\
\hline Schooling & & & $\begin{array}{c}-0.008 * * * \\
(0.001)\end{array}$ & & $\begin{array}{c}-0.005 * * * \\
(0.001)\end{array}$ \\
\hline Cognitive ability & & & & $\begin{array}{c}-0.009 * * * \\
(0.001)\end{array}$ & $\begin{array}{c}-0.007 * * * \\
(0.001)\end{array}$ \\
\hline Non-cognitive ability & & & & $\begin{array}{c}-0.006 * * * \\
(0.001)\end{array}$ & $\begin{array}{c}-0.005^{* * *} \\
(0.001)\end{array}$ \\
\hline Sibling fixed effects & No & Yes & Yes & Yes & Yes \\
\hline Occupation fixed effects & No & No & No & No & Yes \\
\hline Controls for marital status & No & No & No & No & Yes \\
\hline R-squared & 0.008 & 0.004 & 0.005 & 0.008 & 0.009 \\
\hline No. of observations & & & 283,495 & & \\
\hline
\end{tabular}




\section{Figures}

Figure 1: A nonlinear graph of the relationship between global health and earnings

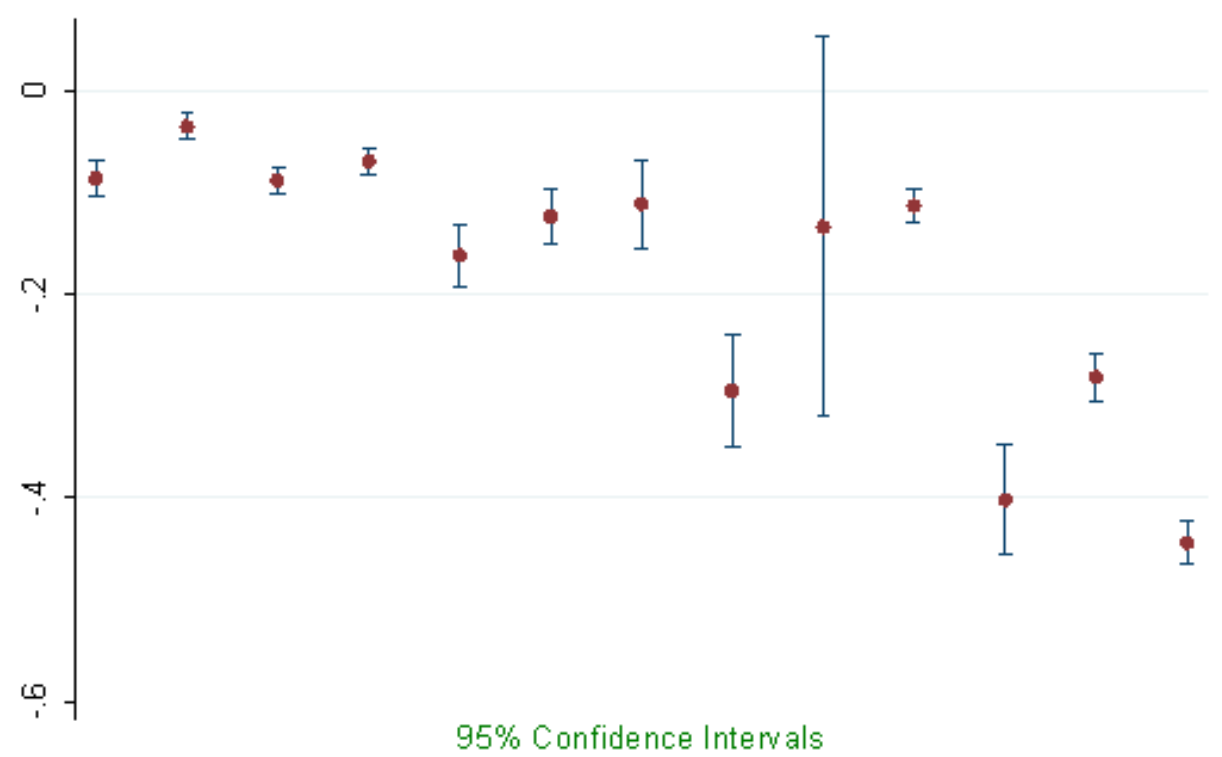

Notes: The graph shows estimates and confidence intervals from a model similar to Model A in

Table 2, but where dummies for different values of global health have been used 


\section{Web Appendix}

Web table 1: U.S. evidence on incidences or prevalences of broad groups of health problems in young ages

\begin{tabular}{|c|c|c|c|c|c|c|}
\hline Study & Diagnoses & $\begin{array}{l}\text { Information } \\
\text { sources }\end{array}$ & $\begin{array}{l}\text { Age } \\
\text { range }\end{array}$ & Sample size & Rates & Note \\
\hline \multicolumn{7}{|l|}{ Tumors } \\
\hline $\begin{array}{l}\text { Wu et al. } \\
(2005)\end{array}$ & Invasive cancer & $\begin{array}{l}22 \text { population- } \\
\text { based cancer } \\
\text { registries }\end{array}$ & $\begin{array}{l}15-19 \\
\text { years }\end{array}$ & $\begin{array}{l}47 \% \text { of the } \\
\text { U.S popu- } \\
\text { lation }\end{array}$ & $\begin{array}{l}0.02 \% \\
\text { incidence per } \\
\text { person-year }\end{array}$ & $\begin{array}{l}\text { White } \\
\text { males } \\
\text { only }\end{array}$ \\
\hline \multicolumn{7}{|c|}{ Endocrine, nutritional and metabolic disorders } \\
\hline $\begin{array}{l}\text { Collins } \\
(1993)\end{array}$ & $\begin{array}{l}\text { Selected } \\
\text { chronic } \\
\text { conditions }\end{array}$ & $\begin{array}{l}\text { National } \\
\text { Health } \\
\text { Interview } \\
\text { Survey 1986- } \\
88\end{array}$ & $\begin{array}{l}<18 \\
\text { years; } \\
18-44 \\
\text { years }\end{array}$ & $\begin{array}{l}307,221 \\
\text { individuals } \\
\text { (without age } \\
\text { restrictions) }\end{array}$ & $\begin{array}{l}0.3 \% ; 1.5 \% \\
\text { prevalence }\end{array}$ & $\begin{array}{l}\text { Males } \\
\text { only }\end{array}$ \\
\hline \multicolumn{7}{|c|}{ Mental conditions } \\
\hline $\begin{array}{l}\text { Merikan- } \\
\text { gas et al. } \\
(2010)\end{array}$ & $\begin{array}{l}\text { Mood, anxiety, } \\
\text { behavior and } \\
\text { substance use } \\
\text { disorders }\end{array}$ & $\begin{array}{l}\text { Nationally } \\
\text { representa-tive } \\
\text { face-to-face } \\
\text { survey }\end{array}$ & $\begin{array}{l}17-18 \\
\text { years; } \\
13-18 \\
\text { years; }\end{array}$ & $\begin{array}{l}2,356 \\
\text { individuals } \\
\text { aged } 17-18 ; \\
10,123 \text { aged } \\
13-18\end{array}$ & $\begin{array}{l}57 \% ; 50 \% \\
\text { prevalence ( } 22 \\
\% \text { with severe } \\
\text { impairment) }\end{array}$ & - \\
\hline $\begin{array}{l}\text { Shaffer et } \\
\text { al. (1996) }\end{array}$ & $\begin{array}{l}\text { Mood, anxiety, } \\
\text { psychosis, } \\
\text { disruptive, } \\
\text { substance use } \\
\text { and other } \\
\text { disorders }\end{array}$ & $\begin{array}{l}\text { Interviews } \\
\text { performed } \\
\text { with random } \\
\text { individuals at } \\
\text { four different } \\
\text { sites }\end{array}$ & $\begin{array}{l}9-17 \\
\text { years }\end{array}$ & $\begin{array}{l}1,285 \\
\text { individuals }\end{array}$ & $\begin{array}{l}\text { Between } 5 \% \\
\text { and } 51 \% \\
\text { prevalence } \\
\text { depending on } \\
\text { the strictness } \\
\text { of criteria }\end{array}$ & - \\
\hline \multicolumn{7}{|c|}{ Conditions of the nervous system } \\
\hline $\begin{array}{l}\text { Collins } \\
(1993)\end{array}$ & $\begin{array}{l}\text { Migraine, } \\
\text { epilepsy and } \\
\text { paralysis }\end{array}$ & $\begin{array}{l}\text { National } \\
\text { Health } \\
\text { Interview } \\
\text { Survey 1986- } \\
88\end{array}$ & $\begin{array}{l}<18 \\
\text { years; } \\
18-44 \\
\text { years }\end{array}$ & $\begin{array}{l}307,221 \\
\text { individuals } \\
\text { (without age } \\
\text { restrictions) }\end{array}$ & $\begin{array}{l}2 \% ; 4 \% \\
\text { prevalence }\end{array}$ & $\begin{array}{l}\text { Males } \\
\text { only }\end{array}$ \\
\hline \multicolumn{7}{|c|}{ Conditions of the sensory organs } \\
\hline $\begin{array}{l}\text { Collins } \\
(1993)\end{array}$ & $\begin{array}{l}\text { Selected } \\
\text { impairments } \\
\text { and chronic } \\
\text { conditions } \\
\text { (visual and } \\
\text { hearing) }\end{array}$ & $\begin{array}{l}\text { National } \\
\text { Health } \\
\text { Interview } \\
\text { Survey 1986- } \\
88\end{array}$ & $\begin{array}{l}<18 \\
\text { years; } \\
18-44 \\
\text { years }\end{array}$ & $\begin{array}{l}307,221 \\
\text { individuals } \\
\text { (without age } \\
\text { restrictions) }\end{array}$ & $\begin{array}{l}3 \% ; 10 \% \\
\text { prevalence }\end{array}$ & $\begin{array}{l}\text { Males } \\
\text { only }\end{array}$ \\
\hline \multicolumn{7}{|c|}{ Circulatory conditions } \\
\hline $\begin{array}{l}\text { Collins } \\
(1993)\end{array}$ & $\begin{array}{l}\text { Selected } \\
\text { chronic }\end{array}$ & $\begin{array}{l}\text { National } \\
\text { Health }\end{array}$ & $\begin{array}{l}<18 \\
\text { years; }\end{array}$ & $\begin{array}{l}307,221 \\
\text { individuals }\end{array}$ & $\begin{array}{l}3 \% ; 15 \% \\
\text { prevalence }\end{array}$ & $\begin{array}{l}\text { Males } \\
\text { only }\end{array}$ \\
\hline
\end{tabular}




\begin{tabular}{|c|c|c|c|c|c|c|}
\hline & conditions & $\begin{array}{l}\text { Interview } \\
\text { Survey 1986- } \\
88\end{array}$ & $\begin{array}{l}18-44 \\
\text { years }\end{array}$ & $\begin{array}{l}\text { (without age } \\
\text { restrictions) }\end{array}$ & & \\
\hline \multicolumn{7}{|c|}{ Respiratory conditions } \\
\hline $\begin{array}{l}\text { Collins } \\
\text { (1993) }\end{array}$ & $\begin{array}{l}\text { Selected } \\
\text { chronic } \\
\text { conditions }\end{array}$ & $\begin{array}{l}\text { National } \\
\text { Health } \\
\text { Interview } \\
\text { Survey 1986- } \\
88\end{array}$ & $\begin{array}{l}<18 \\
\text { years; } \\
18-44 \\
\text { years }\end{array}$ & $\begin{array}{l}307,221 \\
\text { individuals } \\
\text { (without age } \\
\text { restrictions) }\end{array}$ & $\begin{array}{l}29 \% ; 33 \% \\
\text { prevalence }\end{array}$ & $\begin{array}{l}\text { Males } \\
\text { only }\end{array}$ \\
\hline \multicolumn{7}{|c|}{ Digestive conditions } \\
\hline $\begin{array}{l}\text { Collins } \\
\text { (1993) }\end{array}$ & $\begin{array}{l}\text { Selected } \\
\text { chronic } \\
\text { conditions }\end{array}$ & $\begin{array}{l}\text { National } \\
\text { Health } \\
\text { Interview } \\
\text { Survey 1986- } \\
88\end{array}$ & $\begin{array}{l}<18 \\
\text { years; } \\
18-44 \\
\text { years }\end{array}$ & $\begin{array}{l}307,221 \\
\text { individuals } \\
\text { (without age } \\
\text { restrictions) }\end{array}$ & $\begin{array}{l}3 \% ; 12 \% \\
\text { prevalence }\end{array}$ & $\begin{array}{l}\text { Males } \\
\text { only }\end{array}$ \\
\hline \multicolumn{7}{|c|}{ Genito-urinary conditions } \\
\hline $\begin{array}{l}\text { Collins } \\
(1993)\end{array}$ & $\begin{array}{l}\text { Selected } \\
\text { chronic } \\
\text { conditions }\end{array}$ & $\begin{array}{l}\text { National } \\
\text { Health } \\
\text { Interview } \\
\text { Survey 1986- } \\
88\end{array}$ & $\begin{array}{l}<18 \\
\text { years; } \\
18-44 \\
\text { years }\end{array}$ & $\begin{array}{l}307,221 \\
\text { individuals } \\
\text { (without age } \\
\text { restrictions) }\end{array}$ & $\begin{array}{l}0.3 \% ; 1.6 \\
\% \\
\text { prevalence }\end{array}$ & $\begin{array}{l}\text { Males } \\
\text { only }\end{array}$ \\
\hline \multicolumn{7}{|c|}{ Skin conditions } \\
\hline $\begin{array}{l}\text { Collins } \\
(1993)\end{array}$ & $\begin{array}{l}\text { Selected } \\
\text { chronic } \\
\text { conditions }\end{array}$ & $\begin{array}{l}\text { National } \\
\text { Health } \\
\text { Interview } \\
\text { Survey 1986- } \\
88\end{array}$ & $\begin{array}{l}<18 \\
\text { years; } \\
18-44 \\
\text { years }\end{array}$ & $\begin{array}{l}307,221 \\
\text { individuals } \\
\text { (without age } \\
\text { restrictions) }\end{array}$ & $\begin{array}{l}9 \% ; 13 \% \\
\text { prevalence }\end{array}$ & $\begin{array}{l}\text { Males } \\
\text { only }\end{array}$ \\
\hline \multicolumn{7}{|c|}{ Musculoskeletal conditions } \\
\hline $\begin{array}{l}\text { Collins } \\
\text { (1993) }\end{array}$ & $\begin{array}{l}\text { Selected } \\
\text { chronic } \\
\text { conditions }\end{array}$ & $\begin{array}{l}\text { National } \\
\text { Health } \\
\text { Interview } \\
\text { Survey 1986- } \\
88\end{array}$ & $\begin{array}{l}<18 \\
\text { years; } \\
18-44 \\
\text { years }\end{array}$ & $\begin{array}{l}307,221 \\
\text { individuals } \\
\text { (without age } \\
\text { restrictions) }\end{array}$ & $\begin{array}{l}0.6 \% ; 9 \% \\
\text { prevalence }\end{array}$ & $\begin{array}{l}\text { Males } \\
\text { only }\end{array}$ \\
\hline \multicolumn{7}{|c|}{ Congenital anomalies } \\
\hline $\begin{array}{l}\text { Currie, } \\
\text { Green- } \\
\text { stone and } \\
\text { Moretti } \\
(2011)\end{array}$ & $\begin{array}{l}\text { Any congenital } \\
\text { anomaly }\end{array}$ & $\begin{array}{l}\text { Vital Statistics } \\
\text { Natality } \\
\text { Records }\end{array}$ & $\begin{array}{l}\text { New- } \\
\text { borns }\end{array}$ & $\begin{array}{l}197,464 \\
\text { individuals }\end{array}$ & $\begin{array}{l}1.0 \% \\
\text { prevalence }\end{array}$ & - \\
\hline $\begin{array}{l}\text { Parker et } \\
\text { al. }(2010)\end{array}$ & $\begin{array}{l}\text { Selected active } \\
\text { birth defects }\end{array}$ & $\begin{array}{l}\text { Population- } \\
\text { based data } \\
\text { from active } \\
\text { surveillance } \\
\text { programs }\end{array}$ & $\begin{array}{l}\text { New- } \\
\text { borns }\end{array}$ & $\begin{array}{l}3,120,605 \\
\text { individuals }\end{array}$ & $\begin{array}{l}0.8 \% \\
\text { prevalence }\end{array}$ & - \\
\hline \multicolumn{7}{|l|}{ Injuries } \\
\hline $\begin{array}{l}\text { Adams } \\
\text { and Hardy }\end{array}$ & $\begin{array}{l}\text { Injuries } \\
\text { involving }\end{array}$ & $\begin{array}{l}\text { National } \\
\text { Health }\end{array}$ & $\begin{array}{l}<18 \\
\text { years; }\end{array}$ & $\begin{array}{l}122,310 \\
\text { individuals }\end{array}$ & $\begin{array}{l}0.3 ; 0.3 \text { per } \\
\text { person-year }\end{array}$ & $\begin{array}{l}\text { Males } \\
\text { only }\end{array}$ \\
\hline
\end{tabular}




\begin{tabular}{|c|c|c|c|c|c|c|}
\hline (1989) & $\begin{array}{l}\text { medical } \\
\text { attention or } \\
\text { restricted } \\
\text { activity }\end{array}$ & $\begin{array}{l}\text { Interview } \\
\text { Survey } 1988\end{array}$ & $\begin{array}{l}18-44 \\
\text { years }\end{array}$ & & & \\
\hline $\begin{array}{l}\text { National } \\
\text { Safety } \\
\text { Council } \\
(2007)\end{array}$ & $\begin{array}{l}\text { Nonfatal } \\
\text { unintentional } \\
\text { injuries treated } \\
\text { at emergency } \\
\text { department }\end{array}$ & $\begin{array}{l}\text { NEISS All } \\
\text { Injury } \\
\text { Program (a } \\
\text { sample of } \\
\text { hospitals) } \\
2004\end{array}$ & $\begin{array}{l}15-24 \\
\text { years }\end{array}$ & $\begin{array}{l}\text { About } \\
500,000 \\
\text { injuries } \\
\text { (without age } \\
\text { restrictions) }\end{array}$ & $\begin{array}{l}0.1 \text { per } \\
\text { person-year }\end{array}$ & - \\
\hline $\begin{array}{l}\text { McCaig } \\
\text { and Nawar } \\
(2006)\end{array}$ & $\begin{array}{l}\text { Injury-related } \\
\text { visits to } \\
\text { emergency } \\
\text { departments }\end{array}$ & $\begin{array}{l}\text { National } \\
\text { Hospital } \\
\text { Ambulatory } \\
\text { Medical Care } \\
\text { Survey } 2004\end{array}$ & $\begin{array}{l}15-24 \\
\text { years }\end{array}$ & $\begin{array}{l}\text { About } 500 \\
\text { nationally } \\
\text { represen- } \\
\text { tative } \\
\text { hospitals }\end{array}$ & $\begin{array}{l}0.2 \text { per } \\
\text { person-year }\end{array}$ & $\begin{array}{l}\text { Males } \\
\text { only }\end{array}$ \\
\hline
\end{tabular}


Web table 2: U.S. evidence on incidences or prevalences of specific health problems in young ages

\begin{tabular}{|c|c|c|c|c|c|}
\hline Study & $\begin{array}{l}\text { Information } \\
\text { sources }\end{array}$ & Age range & Sample size & Rates & Note \\
\hline \multicolumn{6}{|l|}{ Diabetes } \\
\hline Collins (1993) & $\begin{array}{l}\text { National Health } \\
\text { Interview } \\
\text { Survey 1986-88 }\end{array}$ & $\begin{array}{l}<18 \text { years; } 18-44 \\
\text { years }\end{array}$ & $\begin{array}{l}307,221 \\
\text { individuals } \\
\text { (without age } \\
\text { restrictions) }\end{array}$ & $\begin{array}{l}0.3 \% ; 0.2 \% \\
\text { prevalence }\end{array}$ & Males only \\
\hline $\begin{array}{l}\text { Data Resource } \\
\text { Center for Child } \\
\text { and Adolescent } \\
\text { Health (2013) }\end{array}$ & $\begin{array}{l}\text { National Survey } \\
\text { of Children's } \\
\text { Health } 2007\end{array}$ & $12-17$ years & $\begin{array}{l}36,262 \\
\text { individuals }\end{array}$ & $\begin{array}{l}0.7 \% \\
\text { prevalence }\end{array}$ & - \\
\hline \multicolumn{6}{|l|}{ Neurosis } \\
\hline $\begin{array}{l}\text { Merikangas et } \\
\text { al. (2010) }\end{array}$ & $\begin{array}{l}\text { Nationally } \\
\text { representative } \\
\text { face-to-face } \\
\text { survey }\end{array}$ & $\begin{array}{l}17-18 \text { years; } 13- \\
18 \text { years; }\end{array}$ & $\begin{array}{l}2,356 \\
\text { individuals aged } \\
17-18 ; 10,123 \\
\text { aged } 13-18\end{array}$ & $\begin{array}{l}32 \% ; 32 \% \\
\text { prevalence ( } 8 \\
\% \text { with severe } \\
\text { impairment) }\end{array}$ & - \\
\hline $\begin{array}{l}\text { Shaffer et al. } \\
(1996)\end{array}$ & $\begin{array}{l}\text { Interviews } \\
\text { performed with } \\
\text { random } \\
\text { individuals at } \\
\text { four different } \\
\text { sites }\end{array}$ & 9-17 years & $\begin{array}{l}1,285 \\
\text { individuals }\end{array}$ & $\begin{array}{l}\text { Between } 3 \% \\
\text { and } 40 \% \\
\text { prevalence } \\
\text { depending on } \\
\text { the strictness } \\
\text { of criteria }\end{array}$ & - \\
\hline $\begin{array}{l}\text { Data Resource } \\
\text { Center for Child } \\
\text { and Adolescent } \\
\text { Health (2013) }\end{array}$ & $\begin{array}{l}\text { National Survey } \\
\text { of Children's } \\
\text { Health } 2007\end{array}$ & $12-17$ years & $\begin{array}{l}34,533 \\
\text { individuals }\end{array}$ & $\begin{array}{l}5 \% \\
\text { prevalence }\end{array}$ & - \\
\hline \multicolumn{6}{|c|}{ Personality disorder } \\
\hline $\begin{array}{l}\text { Johnson et al. } \\
(2000)\end{array}$ & $\begin{array}{l}\text { Interviews with } \\
\text { randomly } \\
\text { sampled } \\
\text { individuals from } \\
\text { two New York } \\
\text { counties }\end{array}$ & $9-19$ years & 717 individuals & $\begin{array}{l}14 \% \\
\text { prevalence }\end{array}$ & - \\
\hline \multicolumn{6}{|c|}{ Alcoholism and drug dependence } \\
\hline $\begin{array}{l}\text { Department of } \\
\text { Health and } \\
\text { Human Services } \\
(2006)\end{array}$ & $\begin{array}{l}2005 \text { National } \\
\text { Survey on Drug } \\
\text { Use and Health }\end{array}$ & $\begin{array}{l}\text { 12-17; } 18 \text { or } \\
\text { older }\end{array}$ & $\begin{array}{l}22,565 ; 45,743 \\
\text { without gender } \\
\text { restrictions }\end{array}$ & $\begin{array}{l}8 \% ; 13 \% \\
\text { past-year } \\
\text { prevalence }\end{array}$ & $\begin{array}{l}\text { Males only. } \\
\text { Nondependent } \\
\text { abuse is included. }\end{array}$ \\
\hline $\begin{array}{l}\text { Shaffer et al. } \\
(1996)\end{array}$ & $\begin{array}{l}\text { Interviews } \\
\text { performed with } \\
\text { random } \\
\text { individuals at } \\
\text { four different } \\
\text { sites }\end{array}$ & 9-17 years & $\begin{array}{l}1,285 \\
\text { individuals }\end{array}$ & $\begin{array}{l}\text { Between } 1.1 \\
\% \text { and } 2 \% \\
\text { prevalence } \\
\text { depending on } \\
\text { the strictness } \\
\text { of criteria }\end{array}$ & - \\
\hline
\end{tabular}




\begin{tabular}{|c|c|c|c|c|c|}
\hline \multicolumn{6}{|l|}{ Epilepsy } \\
\hline Collins (1993) & $\begin{array}{l}\text { National Health } \\
\text { Interview } \\
\text { Survey 1986-88 }\end{array}$ & $\begin{array}{l}<18 \text { years; } 18-44 \\
\text { years }\end{array}$ & $\begin{array}{l}307,221 \\
\text { individuals } \\
\text { (without age } \\
\text { restrictions) } \\
\end{array}$ & $\begin{array}{l}0.4 \% ; 0.5 \% \\
\text { prevalence }\end{array}$ & Males only \\
\hline $\begin{array}{l}\text { Data Resource } \\
\text { Center for Child } \\
\text { and Adolescent } \\
\text { Health (2013) }\end{array}$ & $\begin{array}{l}\text { National Survey } \\
\text { of Children's } \\
\text { Health } 2007\end{array}$ & $12-17$ years & $\begin{array}{l}36,264 \\
\text { individuals }\end{array}$ & $\begin{array}{l}0.9 \% \\
\text { prevalence }\end{array}$ & - \\
\hline \multicolumn{6}{|l|}{ Migraine } \\
\hline Collins (1993) & $\begin{array}{l}\text { National Health } \\
\text { Interview } \\
\text { Survey 1986-88 }\end{array}$ & $\begin{array}{l}<18 \text { years; } 18-44 \\
\text { years }\end{array}$ & $\begin{array}{l}307,221 \\
\text { individuals } \\
\text { (without the age } \\
\text { restrictions) }\end{array}$ & $\begin{array}{l}1.1 \% ; 2.6 \% \\
\text { prevalence }\end{array}$ & Males only \\
\hline $\begin{array}{l}\text { Lipton et al. } \\
(2007)\end{array}$ & $\begin{array}{l}\text { Mailed } \\
\text { questionnaire } \\
\text { followed by } \\
\text { telephone } \\
\text { interview and } \\
\text { voice diary }\end{array}$ & $12-17$ years & $\begin{array}{l}13,951 \\
\text { individuals } \\
\text { (without gender } \\
\text { restrictions) }\end{array}$ & $\begin{array}{l}4.9 \% 1 \text {-year } \\
\text { prevalence }\end{array}$ & - \\
\hline \multicolumn{6}{|l|}{ Asthma } \\
\hline Collins (1993) & $\begin{array}{l}\text { National Health } \\
\text { Interview } \\
\text { Survey 1986-88 }\end{array}$ & $\begin{array}{l}<18 \text { years; } 18-44 \\
\text { years }\end{array}$ & $\begin{array}{l}307,221 \\
\text { individuals } \\
\text { (without age } \\
\text { restrictions) }\end{array}$ & $\begin{array}{l}6 \% ; 3 \% \\
\text { prevalence }\end{array}$ & Males only \\
\hline $\begin{array}{l}\text { Data Resource } \\
\text { Center for Child } \\
\text { and Adolescent } \\
\text { Health (2013) }\end{array}$ & $\begin{array}{l}\text { National Survey } \\
\text { of Children's } \\
\text { Health } 2007\end{array}$ & $12-17$ years & $\begin{array}{l}36,195 \\
\text { individuals }\end{array}$ & $\begin{array}{l}10 \% \\
\text { prevalence }\end{array}$ & - \\
\hline \multicolumn{6}{|l|}{ Hay Fever } \\
\hline Collins (1993) & $\begin{array}{l}\text { National Health } \\
\text { Interview } \\
\text { Survey 1986-88 }\end{array}$ & $\begin{array}{l}<18 \text { years; } 18-44 \\
\text { years }\end{array}$ & $\begin{array}{l}307,221 \\
\text { individuals } \\
\text { (without age } \\
\text { restrictions) }\end{array}$ & $\begin{array}{l}7 \% ; 11 \% \\
\text { prevalence }\end{array}$ & Males only \\
\hline $\begin{array}{l}\text { Data Resource } \\
\text { Center for Child } \\
\text { and Adolescent } \\
\text { Health (2013) }\end{array}$ & $\begin{array}{l}\text { National Survey } \\
\text { of Children's } \\
\text { Health } 2007\end{array}$ & $12-17$ years & $\begin{array}{l}91,455 \\
\text { individuals }\end{array}$ & $\begin{array}{l}16 \% \\
\text { prevalence }\end{array}$ & - \\
\hline \multicolumn{6}{|c|}{ Vertebrogenic pain syndrome } \\
\hline Olsen (1992) & $\begin{array}{l}\text { A questionnaire } \\
\text { filled out by } \\
\text { students in a } \\
\text { Pennsylvania } \\
\text { school district }\end{array}$ & $11-17$ years & $\begin{array}{l}1,242 \\
\text { individuals }\end{array}$ & $\begin{array}{l}30 \% \text { ever } \\
\text { experiencing; } \\
7 \% \text { ever } \\
\text { requiring } \\
\text { medical } \\
\text { attention }\end{array}$ & $\begin{array}{l}\text { Low back pain (an } \\
\text { ICD9 diagnose } \\
\text { similar to } \\
\text { vertebrogenic pain } \\
\text { syndrome in ICD8) }\end{array}$ \\
\hline
\end{tabular}

